\title{
PAYMENTS ON LONG-TERM DEBT AS VOIDABLE PREFERENCES: THE IMPACT OF THE 1984 BANKRUPTCY AMENDMENTS
}

\author{
LISSA LAMKIN BROOME*
}

Bankruptcy law exists, in large part, to secure fairness in the distribution of an insolvent debtor's assets among its creditors. ${ }^{1}$ To prevent the debtor from undermining this goal by transferring its property to a creditor on the eve of bankruptcy, Congress has long provided the bankruptcy trustee with the power to avoid preferential transfers. ${ }^{2}$ The focus of preference law, however, has not been consistent. Prior to the enactment of the Bankruptcy Code (the Code) in 1978, ${ }^{3}$ the trustee could avoid a preferential transfer only if the creditor had reasonable cause to believe the debtor was insolvent. ${ }^{4}$ This suggests that preference law was limited by another objective-that of deterring creditors from scrambling for an advantage as the debtor approached bankruptcys - and was aimed only at preferential transfers received by a creditor who had reason to engage in such untoward behavior. The Code, however, shifted the aim of the preference provision to transfers that impaired the equality of the

- Assistant Professor of Law, University of North Carolina at Chapel Hill. B.S. 1978, University of Illinois; J.D. 1981, Harvard. This project was supported by a grant from the University of North Carolina Law Center Foundation. I wish to thank Caroline Nicholson Bruckel, Larry G. Franceski, S. Elizabeth Gibson, and, especially, Adam H. Broome for their suggestions and insightful cominents on earlier drafts of this article. I also wish to acknowledge the excellent research assistance of Ehzabeth J. Armstrong and Patricia Lewandowski.

1. H.R. REP. No. 595, 95th Cong., 1st Sess. 177-78, reprinted in 1978 U.S. CODE CONG. \& ADMIN. NEws 5963, 6138; S. REP. No. 989, 95th Cong., 2d Sess. 12, reprinted in 1978 U.S. CODE CONG. \& ADMIN. NEWS 5787, 5798.

2. See generally Countryman, The Concept of a Voidable Preference in Bankruptcy, 38 VAND. L. REv. 713, 718-50 (1985) (tracing evolution of American concept of preferential transfers).

3. Bankruptcy Reform Act of 1978, Pub. I. No. 95-598, 92 Stat. 2549. The Bankruptcy Reform Act of 1978 took effect on October 1, 1979. Id. § 402(a), 92 Stat. at 2682.

4. Bankruptcy Act $\S 60 \mathrm{~b}, 11$ U.S.C. $\S 96(\mathrm{~b})$ (1970). The Bankruptcy Act was thoroughly revised by the Bankruptcy Reform Act of 1978, Pub. L. No. 95-598, 92 Stat. 2549, which enacted the new Bankruptcy Code. Throughout this article, citations to the provisions of the former Bankruptcy Act will be given without corresponding references to the new provisions of the Bankruptcy Code.

5. See infra notes $178-79$ and accompanying text. 
bankruptcy distribution without regard to the creditor's state of mind.6 Section 547(b) of the Code provides that the trustee may avoid any transfer made within the ninety-day period before bankruptcy by an insolvent debtor to a creditor on account of an antecedent debt that has the effect of preferring the creditor over other creditors, unless the transfer comes within one of the exceptions provided in section 547(c). ${ }^{7}$ Although a preference provision aimed only at preventing inequality may incidentally deter the scramble for advantage, the Code reflects the judgment that the deterrence objective should not limit the scope of the trustee's avoiding power.

The extent of the trustee's avoiding power under section 547(b), of course, depends on the scope of the exceptions; the section $547(\mathrm{c})^{8}$ exceptions were rather narrowly drawn. Prior to 1984, section 547(c)(2), the so-called ordinary course of business exception, provided that a creditor could retain a preferential transfer in payment of a debt (thus excluding a transfer to secure debt) incurred within forty-five days of the payment, provided the debt was incurred and the payment was made in the ordinary course of business or financial affairs of the debtor and the transfer was made according to ordinary business terms.9 As originally enacted, the exception extended only to preferential transfers in payment of a debt imcurred a short time before the transfer, such as monthly payments of debts for wages, utility services, or inventory and supplies purchased on short-term credit. Although allowing the creditor to retain such a preferential transfer necessarily precluded a complete realization of the goal of equality, Congress thought it important "to leave undisturbed normal financial relations." 10

In 1984, as part of legislation directed primarily at resolving the jurisdictional crisis of the bankruptcy courts, 11 Congress amended the sec-

6. Even after the enactment of the Code, a transfer to an insider of the debtor was preferential if the inside creditor had, at time it received the transfer, reasonable cause to believe the debtor was insolvent. 11 U.S.C. $\$ 547(b)(4)(B)$ (1982). Congress amended section 547(b)(4)(B) in 1984, eliminating the requirement that the creditor have reasonable cause to believe the debtor was insolvent at the time of the transfer. Bankruptcy Amendments and Federal Judgeship Act of 1984, Pnb. L. No. 98-353, § 462(b), 98 Stat. 333, 378.

7. 11 U.S.C. $\S 547(b)$ (1982 \& Supp. III 1985).

8. Id. $\S 547(\mathrm{c})$.

9. $I d . \$ 547(c)(2)(1982)$.

10. H.R. REP. No. 595, 95 th Cong., 1st Sess. 373, reprinted in 1978 U.S. CODE CoNG. \& ADMIN. NEws 5963, 6329; S. REP. No. 989, 95th Cong., 2d Sess. 88, reprinted in 1978 U.S. CODE CoNG. \& ADMm. NEws 5787, 5874.

11. Bankruptcy Amendments and Federal Judgeship Act of 1984, Pub. L. No. 98-353, 98 Stat. 333. The 1984 amendments in large part were a response to the Supreme Court's decision in Northem Pipeline Constr. Co. v. Marathon Pipe Line Co., 458 U.S. 50 (1982). In that case the Supreme Court held that the jurisdictional grant in the Bankruptcy Reform Act of 1978 could not be sustained; bankruptcy judges exercised the essential attributes of Article III judicial power yet did not 
tion $547(c)(2)$ exception to remove the forty-five day limitation.12 Although the amendment appears to be minor, it has potentially signifcant implications for preference law. Most commentators have interpreted this amendment as protecting preferential transfers in payment of long-term debt, emphasizing that the specific forty-five day limitation was the only obstacle to the extension of section 547(c)(2) to payments on long-term debt incurred and paid in the ordimary course of busmess. ${ }^{13}$

enjoy life tenure. Id. at 8487 . The 1984 amendments reconstituted the bankruptcy courts as units of the federal district courts and limited the jurisdiction of the bankruptcy courts. Bankruptcy Amendments and Federal Judgeship Act of 1984, Pub. L. No. 98-353, § 104(a), 98 Stat. 333, 336-41.

12. Bankruptcy Amendments and Federal Judgeship Act of 1984, Pub. L. No. 98-353, § 462(c), 98 Stat. 333, 378.

13. See D. Baird \& T. JaCkson, Cases, Problems, and Materials on Bankruptcy 31718 (1985) (45-day requirement removed in response to concern that section 547(c)(2) should protect "timely principal payments on installment loans"); B. CLARK, THE LAW OF SECuRED TRANSACTHONS UNDER THE UNIFORM COMMERCIAL CODE ( 6.4[2][a], at S6-16 (Supp. 1986) ("This amendment should be of major assistance to Article 9 creditors who receive ordimary course payments on current debt shortly before bankruptcy."); 4 CoLLIER ON BANKRUPTCY If 547.38, at 547-125 (15th ed. 1985) ("As long as a debt is incurred in the ordinary course of the business of the debtor and transferee, payment of that debt will not effect a preference."); R. JORDAN \& W. WARREN, BANKRUPTCY 321 (1985) (noting that 1984 amendment eliminates difficult issue of whether installment payments on bank debt are protected from avoidance by section 547(c)(2)); $R$. LORD \& C. LEWIS, NORTH CAROLINA SECURTY INTEREsTS 220 (1985) ("[B]oth the interest and principal payments [on bank debt], so long as they are made in ordinary course and on ordinary terms, should fall within [section 547(c)(2)] under the 1984 amendinents ... . "); J. WHITE, TEACHER'S MANUAL FOR BANKRUPTCY AND CREDITORS' RJGHTS 45-46 (1985) (suggesting that section 547(c)(2), as amended, should protect payinents by the debtor on installment loans); DeSimone, Section 547(c)(2) of the Bankruptcy Code: The Ordinary Course of Business Exception Without the 45 Day Rule, 20 AKRON L. REV. 95, 129 (1986) (noting that legislative history of 1984 amendinent to section 547(c)(2) does not expressly limit application of section 547(c)(2) to short-term debt, and arguing that to apply it to payments on all debt is more consistent with the policies behind the section); Gorney, Elimination of the 45-Day Rule: Amendment of Section 547(c)(2) Requires a New Look at Preferences, 91 CoM. L.J. 364, 368 (1986) ("Installment debts of both consumer and business debtors paid when due will not be avoidable because 'the date the debt was incurred' lias been eliminated as a measure of the avoidability."); Herbert, The Trustee Versus the Trade Creditor II: The 1984 Amendment ro Section 547(c)(2) of the Bankruptcy Code, 2 BANKR. DEv. J. 201, 213 (1985) ("[P]ayments on long-term debt, such as payments on an unsecured promissory note... are now protected if they fall within the remaining three requirements of Section 547(c)(2)."); Morris, Substantive Consumer Bankruptcy Reform in the Bankruptcy Amendments Act of 1984, 27 WM. \& MARY L. REV. 91, 122-23 (1985) (arguing that the 1984 amendment expands protection of section 547(c)(2) to "virtually all timely payments of installment obligations," even where debtor incurred original debt long ago); Weintraub \& Resnick, Preferential Payment of Long-Term Debts in the Ordinary Course of Business-The Effect of the 1984 Amendments, 17 U.C.C. L.J. 263, 264 (1985) ("The effect of this 1984 amendment is tliat the ordinary course of business exception to the preference rule now applies to long-term as well as short-term debt.").

Only a few observers have objected to extending the protection of section $547(\mathrm{c})(2)$ to payments on long-term debt. Professor Duncan argues that the ordinary course of business requirements should be interpreted strictly to exclude "atypical" financings, such as long-term financings, but offers no further guidance on liow to distinguish "typical" from "atypical" financings. Duncan, Loan Payments to Secured Creditors as Preferences Under the 1984 Bankruptcy Amendments, 64 NEB. L. REV. 83, 90 (1985). Professor Countryman, on the other hand, does not argue for a limiting 
This interpretation is only superficially attractive. Other commentators, offering a more careful analysis, have argued that the amendment should be read as protecting payments on long-term debt because the scant legislative history surrounding the 1984 amendment does not directly indicate an intent to limit the scope of the section, and that protection of payments on long-term debt is consistent with the policy of protecting "normal financial relations." 14

Notwithstanding the commentary, in Aguillard v. Bank of Lafayette (In re Bourgeois), ${ }^{15}$ the first bankruptcy court to address this issue ${ }^{16}$ held that amended section 547(c)(2) does not extend to payments on longterm debt. The court reasoned that Congress inerely intended to remove the arbitrary forty-five day limitation without significantly expanding the scope of the exception. The court also stated that long-term debt is not incurred in the ordimary course of business and that the policy of protecting "normal financial relations" did not justify extending protection to payments on long-tern debt.17

Althougli the issue addressed by the commentators and faced by the court in Bourgeois appears narrow, its resolution will significantly affect the goals of preference law. If Congress's elimination of the forty-five day requirement was ineant to extend protection to payments on longterm debt, the 1984 amendment will reflect yet another shift in the goal of preference law-from that of preserving equality of distribution of the debtor's assets among its creditors to that of avoiding preferential transfers received by creditors under unusual circumstances. If Congress did not intend this radical shift, then what are the outer limits of amended section 547(c)(2)?

interpretation of the amended exception, but advocates its repeal because it "creates a gaping hole in the preference policy by protecting every creditor who receives a payment otherwise avoidable under section 547(b)." Countryman, supra note 2, at 772. A student commentator has also suggested that "Congress did not intend to protect all transfers including long-term installment payments" by eliminating the 45-day provision. Note, Timing of Payments by Check Under Section 547 of the Bankruptcy Code, 7 CARDozo L. REv. 887, 904 (1986). The author suggests that section 547(c)(2) "was designed to protect only those payments made in full satisfaction of a debt in the ordinary course of business." Id. at 907 n.104. See also Dunham \& Price, The End of Preference Liability for Unsecured Creditors: New Section S47(c)(2) of the Bankruptcy Code, 60 IND. L.J. 487, 490, 499, 505-11 (1985) (asserting that "timely payments made on an unsecured note are now within the [ordinary course of business] defense," but presenting some arguments for limited interpretation of section $547(\mathrm{c})(2))$.

14. DeSimone, supra note 13 , at $128-31$.

15. 58 Bankr. 657 (Bankr. W.D. La. 1986).

16. Few cases have arisen under the amended section since it is effective only for those cases filed after October 8, 1984. 4 COLLIER ON BANRRUPTCY ff 547.03[6], at 547-30 (15th ed. 1985).

17. Boungeois, 58 Bankr. at 659 (citing H. REP. No. 595, 95th Cong., 1st Sess. 308, 373, reprinted in 1978 U.S. CODE CONG. \& ADMIN. NEws 5963, 6329). 
This article concludes that section $547(\mathrm{c})(2)$, as originally enacted and as amended in 1984, should not be interpreted as protecting preferential payments on long-term debt. Part I briefly sets forth the elements of a preferential transfer of the debtor's property and the requirements of section 547(c)(2). ${ }^{18}$ Part II presents an extensive examination of the statutory development and legislative history of the preference provision and the section 547(c)(2) exception in an effort to determine Congress's intent regarding the scope of the exception. ${ }^{19}$ Part III examines the policies underlying the preference provision and the exception, and concludes that the exception should be limited to payments on short-terrn debt. ${ }^{20}$

\section{THE STATUTORY FRAMEWORK}

The bankruptcy trustee ${ }^{21}$ has several avoiding powers that enable him to invalidate certain of the debtor's transactions ${ }^{22}$ and recover the affected property for the debtor's estate. ${ }^{23}$ One of the trustee's most important avoiding powers is the power to avoid preferential transfers ${ }^{24}$ pursuant to section 547(b) of the Bankruptcy Code.25 Under section $547(b)$, a transfer ${ }^{26}$ of an interest of the debtor in property is a preferential transfer if it is made (1) to or for the benefit of a creditor in payment of a debt or as security for a debt, (2) on account of an antecedent debt, ${ }^{27}$

18. See infra notes 21-53 and accompanying text.

19. See infra notes 54-167 and accompanying text.

20. See infra notes 168-208 and accompanying text.

21. In a Chapter 11 proceeding, the debtor in possession may exercise the avoiding powers granted to the trustee in a Chapter 7 proceeding. 11 U.S.C. § 1107(a) (Supp. III 1985). Unless otherwise indicated, reference to the trustee in this article also includes the debtor in possession if the proceeding is a Chapter 11 proceeding.

22. E.g., 11 U.S.C. § 544 (1982 \& Supp. III 1985) (power to avoid transaction voidable by lien creditor at time of filing of bankruptcy petition); id. $\S 545$ (power to avoid certain statutory liens); id. $\S 548$ (power to avoid fraudulent conveyances).

23. If avoidance of the transfer is successful, "the trustee may recover, for the benefit of the estate, the property transferred, or, if the court so orders, the value of such property, from-(1) the initial transferee of such transfer . . . or (2) any immediate or mediate transferee of such initial transferee." Id. $\S 550($ a). "Any transfer avoided under [section 547] is preserved for the benefit of the estate but only with respect to property of the estate." Id. §551 (1982).

24. See Countryinan, supra note 2, at 713 ("[None of the avoiding] powers is of more concern to prebankruptcy transferees than the trustee's power to avoid preferential transfers.").

25. 11 U.S.C. $\S 547(b)$ (1982 \& Supp. III 1985). The trustee bears the burden of proving that a transfer is avoidable under $\S 547(\mathrm{~b})$. Id. $\S 547(\mathrm{~g})$ (Supp. III 1985).

26. A transfer is defined as "every mode, direct or indirect, absolute or conditional, voluntary or involuntary, of disposing of or parting with property or with an interest in property, including retention of title as a security interest and foreclosure of the debtor's equity of redemption." Id. $\S 101(48)$.

27. A "debt" is defined as a "hability on a claim." Id. § 101(11) (1982). A "claim" includes a "right to payment, whether or not such right is reduced to judgment, liquidated, unliquidated, fixed, contingent, matured, unmatured, dispuled, undisputed, legal, equitable, secured, or unsecured." Id. $\S 101(4)(A)$. 
(3) while the debtor was insolvent, 28 (4) within ninety days before the filing of the bankruptcy petition, ${ }^{29}$ and if it (5) enables the creditor to receive more than the creditor would otherwise receive in a Chapter 7 liquidation of the debtor's property assuming the transfer had not been made. ${ }^{30}$ Section 547 (b) thus deems preferential any transfer by an insol-

A payment is on account of an antecedent debt if the transfer of payment is deemed made after the debt was incurred. Section $547(\mathrm{e})$ mdicates when a transfer of payment is deemed to be made. 11 U.S.C. $§ 547(e)$ (1982 \& Supp. III 1985). If the transfer was made prior to or contemporaneously with the incurrence of the debt, then the transfer is not on account of an antecedent debt. D. BAIRD \& T. JACKSON, supra note 13 , at $284-85$.

28. An entity is "insolvent" if the "sum of such entity's debts is greater than all of such entity's property, at a fair valuation, exclusive of - (i) property transferred ... with intent to hinder, delay, or defraud such entity's creditors; and (ii) property that may be exempted from property of the estate" 11 U.S.C. § 101(29)(A) (Supp. III 1985).

The debtor is presumed to be insolvent during the 90-day period preceding the filing of the bankruptcy petition. Id. $\S 547(f)$ (1982). If the presumption of insolvency is tebutted by a creditor, the trustee must prove by a preponderance of the evidence that the debtor was insolvent at the time of the transfer. See Sandoz v. Fred Wilson Drilling Co. (In re Emerald Oil Co.), 695 F.2d 833, 83739 (5th Cir. 1983); 4 COLLIER ON BANKRUPTCY I 547.26, at 547-109 to 547-110 (15th ed. 1985).

29. The trustee can attack a transfer to an "insider" within one year prior to the filing of the bankruptcy petition. In the case of a corporate debtor, an insider is defined to imclude a director, officer, or person in control of the debtor, II U.S.C. § 101(28)(B)(1)-(iii) (Supp. III 1985), and in the case of an individual debtor, an insider is defined to mclude a relative of the debtor. Id. $\S 101(28)(\mathrm{A})(\mathrm{i})$. In the case of a transfer made to an insider between 90 days and one year prior to the filing of the bankruptcy petition, the trustee does not have the benefit of a statutory presumption of insolvency, but must prove that the debtor was insolvent at the time of the transfer. See id. $\S 547(f)$ (1982) (presumption of insolvency extends back only 90 days). Prior to 1984, the insidertransferee must also have had "reasonable cause to believe the debtor was insolvent at the time of such transfer." Id. § 547(b)(4)(B)(ii) (1982), amended by Bankruptcy Amendments and Federal Judgeship Act of 1984, Pub. L. No. 98-353, § 462(b)(2), 98 Stat. 333, 378. It las been suggested that the removal of the "reasonable cause to believe" requirement for transfers to insiders was not intentional, but rather a "legislative accident." Countryman, supra note 2, at 732.

30. The transfer to an unsecured or undersecured creditor is preferential, assuming, as is the case in virtually all bankruptcy proceedings, that upon liquidation the debtor's assets are not suffcient to satisfy the claims of all creditors in full. A fully secured creditor would be entitled to receive the value of its collateral in a Chapter 7 proceeding; it would therefore not be better off as a result of payment. See, e.g., Roemelmeyer v. Waiter E. Heller \& Co. (In re Lackow Bros.), 752 F.2d 1529, 1531 (11th Cir. 1985); A.I. Credit Corp. v. Drabkin (In re Auto-Train Corp.), 49 Bankr. 605, 609-10 (D.D.C. 1985); Armstrong v. Hustad (In re Flaten), 50 Bankr. 186, 195-96 (Bankr. D.N.D. 1985); Braunstein v. Eastern Airline Employees Fed. Credit Union (In re Fitzgerald), 49 Bankr. 62, 65 (Bankr. D. Mass. 1985); Erman v. Armco, Inc. (In re Formed Tubes, Inc.), 41 Bankr. 819, 821-22 (Bankr. E.D. Mich. 1984); In re Santoro Excavating, Inc., 32 Bankr. 947, 948 (Bankr. S.D.N.Y. 1983); 2 D. CoWANS, COWANS BaNkRuprCY LAW Practice $\$ 10.7$, at 130-31 (1980).

The fully secured creditor must not only comply with Article 9 of the Uniform Commercial Code regarding attachment and perfection of its security interest, but must also take care that its security interest is perfected promptly after its creation in accordance with the requirements of 11 U.S.C. § 547(e) (1982 \& Supp. III 1985). The Bankruptcy Code provides that a transfer of a security interest takes effect between the transferor and transferee at the time the transfer is made if the transfer is perfected on or within 10 days after the transfer is made. Id. $\S 547(\mathrm{e})(2)(\mathrm{A})(1982)$. The transfer is made at the time the transfer is perfected if the transfer is perfected more than 10 days after the transfer is made. $I d$. $\S 547(\mathrm{e})(2)(\mathrm{B})$. The transfer is deemed to be made immediately before the date of the filing of the bankruptcy petition if the transfer is not perfected at the later of the 
vent debtor during the preference period that gives a creditor an advantage over the other creditors who must look to the remaining assets of the debtor for the satisfaction of their claims.

Section $547(c)^{31}$ sets forth seven exceptions that may limit the trustee's ability to avoid some transfers pursuant to section 547(b). The ordinary course of busmess exception, section 547(c)(2), as amended in 1984, provides:

The trustee may not avoid under this section a transfer

…

(2) to the extent that such transfer was-

(A) in payment of a debt imcurred by the debtor in the ordinary course of business or financial affairs of the debtor and the transferee; (B) made in the ordinary course of business or financial affairs of the debtor and the transferee; and

(C) made according to ordinary business terms. ${ }^{32}$

It is easy to draw some explicit distinctions from the text of section 547(c)(2). Two of the three "ordinary" requirements, sections $547(\mathrm{c})(2)(B)$ and $(\mathrm{C})$, relate to the transfer of payment; the remaining requirement, section $547(\mathrm{c})(2)(\mathrm{A})$, relates to the incurrence of the underlying debt. In applying section 547(c)(2), however, inost courts have not carefully distinguislied the separate requirements. ${ }^{33}$

commencement of the case or 10 days after the transfer takes effect between the transferor and the transferee. Id. $\S 547(\mathrm{e})(2)$ (C) (1982 \& Supp. III 1985). In addition, a transfer is deemed not to be made until the debtor has acquired rights in the property transferred. Id. $\S 547(\mathrm{e})(3)(1982)$.

A transfer to an undersecured creditor is a preference. If the payment had not been made, then upon the debtor's bankruptcy the creditor's claim is considered to be two separate claims: a secured clain "to the extent of the value of such creditor's interest in the ... property ... [and] an unsecured claim to the extent that the value of such creditor's interest . . . is less than the amount of such allowed claim." Id. $\$ 506(a)$. Thus,

to the extent that a creditor possesses an allowable secured claim ... it cannot be the recipient of a preference. ... To the extent that the same creditor's claim is unsecured, however, the claim must be considered in the class of general creditors, subject to rules of priority where applicable, and entitled to distribution only pro rata with other general claims.

Armstrong v. Marine Bank Dane County (In re Prescott), 51 Bankr. 751, 754-55 (Bankr. W.D. Wis. 1985); accord Barash v. Public Fin. Corp., 658 F.2d 504, 508-09 (7th Cir. 1981); Auto-Train Corp., 49 Bankr. at 611; Countryman, supra note 2, at 744. But see Taylor v. Fairhope Floor Covering \& Interiors (In re K. Pritchard Co.), 17 Bankr. 508, 509 (Bankr. S.D. Ala. 1981) (criticizing Barash because it "assumes that (a) the creditor receiving the pre-petition transfer has filed a claim in the proceeding and (b) upon distribution of the estate its prior recovery on the debt would be ignored").

31. 11 U.S.C. $\$ 547$ (c) (1982 \& Supp. III 1985). The creditor bears the burden of proving that its entitlement comes within one of the section 547(c) exceptions. Id. $\S 547(\mathrm{~g})$ (Supp. III 1985).

32. Id. $\$ 547(c)(2)$ (Supp. III 1985).

33. Soon after the Bankruptcy Reform Act of 1978 was passed, commentators recognized the interpretive problem of determining whether the ordinary course requirements had been met. See Countryman, Bankruptcy Preferences-Current Law and Proposed Changes, 11 U.C.C. L.J. 95, 102 (1978); Weintraub \& Resnick, supra note 13, at 266; Young, Preferences Under the Bankruptcy Reform Act of 1978, 54 AM. BANKR. L.J. 221, 228-29 (1980); see also Note, Avoidance of Preferential Transfers Under the Bankruptcy Reform Act of 1978, 65 IowA L. REv. 209, 236 (1979) ("If not 
The two requirements relating to the transfer of payment can be best understood as an attempt to inhibit creditors from scrambling for advantage and debtors from preferring one creditor over others for no justifiable reason. Unusual circumstances surrounding a transfer justify questioning whether the transfer is preferential. Section 547(c)(2)(B) focuses on unusual payment circumstances by requiring that payment of the debt be "made in the ordinary course of business or financial affairs of the debtor and the transferee." 34 What is "ordinary" is judged by considering the prior course of dealings between the debtor and the creditor. ${ }^{35}$ Courts generally find that late, early, or inflated payments are not made in the ordinary course of business. ${ }^{36}$ Payments that are several days late, however, may be in the ordinary course of business if late payment is routinely accepted by the creditor. ${ }^{37}$ If the debtor pays substantially later than the establislied late payment period, however, the payment will probably not be considered made in the ordinary course of business. ${ }^{38}$

narrowly construed, the 'ordinary course' exception could provide a loophole that would signifcantly weaken the entire structure of the preference law.").

The majority of cases, however, addressed only the question whether the 45-day requirement had been met. One commentator reports that "[0]f the cases reported in the first 40 volumes of West's Bankruptcy Reporter, which dealt with $\$ 547$ (c)(2), the 45-day requirement appears to have been raised three times more frequently than all the other requirements of that subsection combimed." Nutovic, The Bankruptcy Preference Laws: Interpreting Code Sections 547(c)(2), 550(a)(1), and 546(a)(I), 41 Bus. LAw. 175, 177 n.11 (1985); see also Aguillard v. Bank of Lafayette (In re Bourgeois), 58 Bankr. 657, 658 (Bankr. W.D. La. 1986) (before 45-day requirement was eliminated, most litigation focused on determining when debt was "incurred," not on other elements of section 547(c)(2)); Ewald Bros. v. Kraft, Inc. (In re Ewald Bros.), 45 Bankr. 52, 56-57 (Bankr. D. Minn. 1984) (most litigation under section $547(\mathrm{cc})(2)$ has focused on 45-day requirement and few decisions have addressed other elements of the exception); Duncan, supra note 13, at 88-89 (pre-1984 cases focused on application of 45-day rule, providing little guidance as to meaning of "ordinary course").

After the 45-day requirement was removed, concern shifted to the ordinary course of bnsiness requirements. See D. BAIRD \& T. JACKSON, supra note 13, at 319; T. CRANDALI, R. HAGEDORN \& F. SMITH, DeBtoR-CREDITOR LAW MANUAL If 16.04[7][b], at 16-32 to 16-33 \& n.75 (1985); DeSimone, supra note 13, at $113 \mathrm{nn} .152-53$; Dunham \& Price, supra note 13, at 509; Herbert, supra note 13, at 204; Nutovic, supra, at 181-86; Weintraub \& Resmick, supra note 13, at 266.

34. 11 U.S.C. $\$ 547$ (c)(2)(B) (Supp. III 1985).

35. See, eg., In re Magic Circle Energy Corp., 64 Bankr. 269, 273 (Bankr. W.D. Okla. 1986); Newton v. Ed's Supply Co. (In re White), 58 Bankr. 266, 269-70 (Bankr. E.D. Tenn. 1986); Production Steel, Inc. v. Sumitomo Corp. of Am. (In re Production Steel, Inc.), 54 Bankr. 417, 423 (Bankr. M.D. Tenn. 1985); Ewald Bros, 45 Bankr. at 57.

36. See, eg., Marathon Oil Co. v. Flatau (In re Craig Oil Co.), 785 F.2d 1563, 1567-68 (11th Cir. 1986); Production Steel, 54 Bankr. at 424; Ledford v. Sears, Roebuck \& Co. (In re Williams), 5 Bankr. 706, 707 (Bankr. S.D. Ohio 1980).

37. See Craig Oil Co., 785 F.2d at 1567 (in light of parties' prior course of dealing, payments within six days after due date were ordinary).

38. See id; Ewald Bros., 45 Bankr. at 59 (payments that were seven, nine, and twelve days late were not in ordinary course of business where creditor previously liad accepted payments one or two days after they were due). 
The requirement of section 547(c)(2)(C) that the payment be "made according to ordinary business terms" 39 is less clear. Unlike sections $547(\mathrm{c})(2)(\mathrm{A})$ and (B), section 547(c)(2)(C) does not refer to the ordinary course between the "debtor and the transferee."40 This omission suggests that the business terms of the transaction must be ordinary in an objective sense. Thus, the transfer must coincide with industry practice, ${ }^{41}$ as well as the debtor's and transferee's practices in making and accepting payments. ${ }^{42}$ If the transfer is imconsistent with objective industry standards, doubt is cast on the claim that the transfer was in the ordinary course of the debtor's and transferee's business. Despite their ambiguities, the two provisions relating to the transfer of payment are designed to ensure that neither the debtor nor the creditor does anything out of the ordinary to gain advantage over other creditors. ${ }^{43}$

Section 547(c)(2)(A)'s requirement that the underlying debt be "incurred by the debtor in the ordinary course of business or financial affairs of the debtor and the transferee"44 is nore problematic, since it seems divorced from the notion of preserving equality and preventing creditor or debtor misbehavior. The few cases decided under section $547(\mathrm{c})(2)(\mathrm{A})$ have involved the requirement that the loan be in the ordinary course of business of the transferee. Although the ordinary course of business for a bank includes the extension of credit, ${ }^{45}$ courts have found that loans by

Section $547(c)(2)(B)$ 's reference to the ordinary course of the "financial affairs" as well as the "business" of the debtor and the transferee may appear to expand the exception. Congress inserted the "financial affairs" language, however, to clarify that the exception also protects consumers in noncommercial transactions for whom the "ordinary course of business" language would not be applicable. See H.R. RER. No. 595, 95th Cong., 1st Sess. 373, reprinted in 1978 U.S. CODE CONG. \& ADMIN. NEwS 5963, 6329; S. REP. No. 989, 95th Cong., 2d Sess. 88, reprinted in 1978 U.S. CODE CONG. \& ADMIN. NEWS 5787, 5874.

39. 11 U.S.C. $\S 547(\mathrm{C})(2)(C)$ (Supp. III 1985).

40. Id. $\S 547(\mathrm{c})(2)(\mathrm{A})$.(B).

41. See In re Magic Circle Energy Corp., 64 Bankr. 269, 275 (Bankr. W.D. Okla. 1986); Production Steel, Inc. v. Sumitomo Corp. of Am. (In re Production Steel, Inc.), 54 Bankr. 417, 424 (Bankr. M.D. Tenn. 1985).

42. See Sassoon v. International Multifoods Corp. (In re Coastal Fisheries, Inc.), 57 Bankr. 657, 659 (Bankr. D. Mass. 1986).

43. See Marathon Oil Co. v. Flatau (In re Craig Oil Co.), 785 F.2d 1563, 1566 (11th Cir. 1986) (section 547(c)'s ordinary course of business requirements evince congressional intent to protect payments that "do not result from 'unusual' debt collection or payment practices"); Campbell v. Cannington (In re Economy Milling Co.), 37 Bankr. 914, 922 (D.S.C. 1983) ("[O]nly unusual or abnormal actions by the parties to collect or pay on an existing debt are proscribed."); Production Steel, 54 Bankr. at 423 ("The exercise of leverage by [the creditor] in the ways indicated takes this transaction out of the class of ordinary course transactions intended to be protected by $\S 547(\mathrm{c})(2) . ")$.

44. 11 U.S.C. $\S 547(0)(2)$ (A) (Supp. III 1985) (emphasis added).

45. In re Cascade Oil Co., 51 Bankr. 877, 882 (Bankr. D. Kan. 1985); see also Aguillard v. Bank of Lafayette (In re Bourgeois), 58 Bankr. 657, 660 (Bankr. W.D. La. 1986) ("Iong-term loans may be ordinary to the banks"). 
shareholders or insiders are not in the ordinary course of the shareholder's or insider's business. ${ }^{46}$ If the debtor must borrow from such an unusual source, this may indicate that more conventional financing is not available because the debtor is in poor financial condition.

The requirement that the loan also be incurred in the ordinary course of the debtor's business has received even less judicial attention. Presumably, a loan from a source not usually used by the debtor, such as a loan shark, will not be deemed incurred in the ordinary course of the debtor's business. ${ }^{47}$ As originally enacted, section $547(c)(2)$ excepted froin avoidance only payments inade within forty-five days of a debt's incurrence. Therefore, the courts did not have to consider whether a long-term debt could be incurred in the ordinary course of the debtor's business. Following the removal of the forty-five day requirement in 1984, courts must now face that question. 48

The Code does not define the phrase "ordinary course of business" and other sections that employ the phrase give little guidance as to its meaning. ${ }^{49}$ In Aguillard v. Bank of Lafayette (In re Bourgeois), ${ }^{50}$ the only case under amended section 547(c)(2) to discuss whether long-term debt may be incurred in the ordinary course of business, ${ }^{51}$ the bankruptcy court concluded that a long-term debt was not incurred by the debtor in the ordinary course of its business.52 Unfortunately, the re-

46. See, e.g., Waldschmidt v. Ranier (In re Fulghum Constr. Corp.), 45 Bankr. 112, 116 (Bankr. M.D. Tenn. 1984); Carter v. Pickens (In re Arctic Air Conditioning, Inc.), 35 Bankr. 107, 110 (Bankr. E.D. Tenn. 1983).

47. See Dunham \& Price, supra note 13 , at 500 .

48. Weisberg, Commercial Morality, the Merchant Character, and the History of the Voidable Preference, 39 STAN. L. REV. 3, 133 (1986) ("The next great statutory episode in preference law may ... be an essentially common law effort to create some criteria for determining when credit transactions meet the norm of 'the ordinary course.' "). Most commentators believe that payments on longterm debt may be protected from avoidance by amended section $547(\mathrm{c})(2)$. See supra note 13.

49. Cf. Committee of Asbestos-Related Litigants and/or Creditors v. Johns-Manville Corp. (In re Johns-Manville Corp.), 60 Bankr. 612, 616 (Bankr. S.D.N.Y. 1986) ("[N] either the Code nor the legislative history of $\S 363$ provide any test or guidelines for identifying an ordinary course transaction.").

50. 58 Bankr. 657 (Bankr. W.D. La. 1980).

51. Two other reported cases discuss the treatment of payments on long-term debt. The bankruptcy court in In re Technology for Energy Corp., 56 Bankr. 307, 317 (Bankr. E.D. Tenn. 1985), stated that if a bank creditor was deemed an insider so that payments to it within one year prior to debtor's bankruptcy could be attacked as preferential, section $547(\mathrm{c})(2)$ might protect from avoidance those payments that were "routine installments." In the second case, In re Magic Circle Energy Corp., 64 Bankr. 269, 273-75 (Bankr. W.D. Okla. 1980), the bankruptcy court held that payment of a long-term promissory note executed pursuant to workout of overdue trade receivables was in the ordinary course of business of the debtor because the workout of overdue trade credit was ordinary in the troubled oil and gas industry. The court in Magic Circle did not hold that a longterm debt could be incurred in the ordinary course of business, since the debt was a short-term trade debt when originally incurred.

52. Bourgeois, 58 Bankr. at 660 . 
ported opinion provides few of the facts surrounding the transfer, other than that the loan was long-term and the creditor was a bank. Nonetheless, the court stated that long-term loans are

a form of capitalization which is not generally part of the debtor's day to day business activities. Thus, although long-term loans may be ordinary to the banks, they are not the ordinary course of business of the debtor within the meaning of ... section 547(c)(2). "Ordinary course" refers to the debtor's normal business operations of selling goods or providing services, not borrowing money.53

To determine whether the result reached by the court in Bourgeois is correct, it is necessary to examine the legislative history and the poticies of the preference provision and the ordinary course of business exception.

\section{THE HISTORY OF THE ORDINARY COURSE OF BUSINESS EXCEPTION}

Congress hastily eliminated the forty-five day requirement froin the ordinary course of business exception, ${ }^{54}$ and the legislative history accompanying the 1984 amendments is scant. Neither the House nor the Senate held hearings on the bill. No House or Senate report was issued to accompany the bill, and the Conference Report contains only the text of the bill and no joint explanatory statement.55 In the absence of any direct indication of congressional intent to expand the coverage of section 547(c)(2) to include protection of payinents on long-term debt, one must consider the fundamental changes in the bankruptcy law made by Congress in $1978^{56}$ as well as the legislative proposals discussed by Congress between the enactment of the Code in 1978 and the 1984 amendments to determine the proper interpretation of the amended section.

\section{A. The Bankruptcy Act of 1898.}

The Bankruptcy Act of 1898 (the 1898 Act), ${ }^{57}$ was the first signif-

53. Id.

54. The hasty elimination of the 45-day requirement was due in part to Congress's preoccupation with the jurisdictional crisis facing the bankruptcy court system. See supra note 11.

55. See H.R. CoNF. REP. No. 882,98 th Cong., 2d Sess, reprinted in 1984 U.S. CODE CoNG. \& ADMIN. NEWS 576.

56. For a general discussion of the legislative history of the Bankruptcy Reform Act of 1978, see H.R. REP. No. 595, 95th Cong., 1st Sess. 2-3, reprinted in 1978 U.S. CoDE CONG. \& ADMIN. NEws 5963, 5963.65; Butler, A Congressman's Reflections on the Drafting of the Bankruptcy Code of 1978, 21 WM. \& MARY L. REv. 557 (1980); Klee, Legislative History of the New Bankruptcy Law, 28 DE PAUL L. REV. 941 (1979). Virtually every document relating to the legislative history of the Bankruptcy Reform Act of 1978 is collected in BANKRUPTCY REFORM ACT OF 1978: A LEGISLATIVE HiSTORY (A. Resnick \& E. Wypyski eds. 1979).

57. Ch. 541, 30 Stat. 544, repealed by Bankruptcy Reform Act of 1978, Pub. L. No. 95-598, § 401(a), 92 Stat. 2549, 2682. 
cant bankruptcy legislation of the United States. As amended, it remained in effect for eighty years. ${ }^{58}$ The 1898 Act was designed to help the debtor seek discharge from debts and to treat the debtor's creditors in an equal manner in the division of the debtor's assets. ${ }^{59}$ The trustee's avoiding powers, including the section 60 power to avoid a preferential transfer of property by the debtor to a creditor, furthered the equality of distribution principle.

Section 60a defined a preference as:

a transfer ... of any of the property of a debtor to or for the benefit of a creditor for or on account of an antecedent debt, made ... by such debtor while insolvent and within four months before the filing by or against him of the petition [in bankruptcy] ... the effect of which transfer will be to enable such creditor to obtain a greater percentage of his debt than some other creditor of the same class. ${ }^{60}$

The trustee could avoid a preferential transfer pursuant to section $60 \mathrm{~b}$, however, only if the creditor receiving the transfer had, at the time the transfer was made, "reasonable cause to beheve that the debtor [was] insolvent."61 This requirement reflected Congress's reluctance to interfere with ordinary business transactions made in good faith. ${ }^{62}$ Thus, the provision gave some measure of security to creditors who were unaware of the debtor's insolvency.63 For example, transfers involving the debtor's payment of a routine bill, such as a nonthly utility bill, were protected by section $60 \mathrm{~b}$ because the creditor usually lacked reasonable cause to beheve that the debtor was insolvent.64

The 1898 Act did not contain any explicit exceptions to sections 60a and $60 \mathrm{~b}$. A judicially created "current expense" rule, however, was developed in cases involving creditor allegations regarding the debtor's intent to prefer. Creditors filing an involuntary petition under the 1898 Act were required to establish that the debtor had committed one or

58. Prior to the 1898 Act, Congress had enacted three short-lived national bankruptcy laws: the Bankruptcy Act of 1800, ch. 19, 2 Stat. 19, repealed by Act of Dec. 19, 1803, ch. 6, 2 Stat. 248; the Bankruptcy Act of 1841, ch. 9, 5 Stat. 440, repealed by Act of Mar. 3, 1843, ch. 82, 5 Stat. 614; and the Bankruptcy Act of 1867, ch. 176, 14 Stat. 517, repealed by Act of June 7, 1878, ch. 160, 20 Stat. 99.

59. 3 Collier ON BANKRuptCy II 60.01, at 743 (14th ed. 1974).

60. Bankruptcy Act $\S 60$ a, 11 U.S.C. $\S 96(a)(1)$ (1970) (repealed 1978).

61. Id. $\$ 60 \mathrm{~b}, 11$ U.S.C. $\$ 96(\mathrm{~b})$ (repealed 1978).

62. 3 COLLIER ON BANKRUPTCY \60.52[2], at 1056 (14th ed. 1974).

63. Queenan, The Preference Provisions of the Pending Bankruptcy Law, 82 CoM. L.J. 465, 467 (1977); Setigson, The Code and the Bankruptcy Act: Three Views on Preferences and After-Acquired Property, 42 N.Y.U. L. REV. 292, 292 (1967).

64. See, e.g., In re Douglas Coal \& Coke Co., 131 F. 769, 778 (E.D. Tenn. 1904); see also Morris, Bankruptcy Law Reform: Preferences, Secret Liens and Floating Liens, 54 MINN. L. REV. $737,762-63$ (1970). 
more acts of bankruptcy. ${ }^{65}$ Prior to 1952, a debtor's preferential transfer for the benefit of a creditor was an act of bankruptcy if the petitioning creditors could show that the debtor intended to prefer the transferee. ${ }^{66}$ Under the current expense rule, the petitioning creditors could not establish that the debtor intended a preference if tlie debtor made a payment for a current expense. Rather, the debtor was held to be merely making "ordinary" payments or payments necessary to the continuation of the business. ${ }^{67}$ In addition, some courts and commentators interpreting the 1898 Act recognized the current expense rule as an exception to the definition of an antecedent debt. 68 These courts and commentators apparently believed that "ordinary," short-term transactions should not be

65. 1 Collier on BANKRUPTCY I 3.03, at 404 (14th ed. 1974).

66. Id. II 3.01[3], 3.206. After 1952, a preferential transfer, as defined in section 60 , was treated as an act of bankruptcy which provided a basis for filing an involuntary petition in bankruptcy under the 1898 Act. Bankruptcy Act $\S 3 \mathrm{a}(2)$, as amended by Act of July 7, 1952, ch. 579, § 3(a), 66 Stat. 420, 421, 11 U.S.C. § 21a(2) (1976) (repealed 1978).

67. See Goodlander-Robertson Lumber Co. v. Atwood, 152 F. 978, 979 (4th Cir. 1907); Richmond Standard Steel Spike \& Iron Co. v. Allen, 148 F. 657, 662 (4th Cir. 1906); In re E.T. Russell Co., 291 F. 809, 813-14 (D. Mass. 1923); In re Columbia Real Estate Co., 205 F. 980,982 (D.N.J. 1913); In re Hallin, 199 F. 806, 808 (W.D. Mich. 1912); In re Morgan \& Williams, 184 F. 938, 94041 (N.D. Ga. 1911); In re Perlhefter, 177 F. 299, 304 (S.D.N.Y. 1910); In re Douglas Coal \& Coke Co., 131 F. 769, 776 (E.D. Tenn. 1904).

It has been suggested that this line of cases was relied on, "with no help from, or regard for, the langunge of [section 60]," by the few conrts that also held that payments of current expenses were not preferences under section 60 , Countryman, supra note 2 , at 768 , and that these cases in turn led the influential Collier bankruptcy treatise to declare that "payments on account of current expenses ... are generally not within the category of preferential transfers." 3 COLLIER ON BANKRUPTCY II 60.23, at 873 (14th ed. 1974), quoted in Countryman, supra note 2, at 768.

68. See Marshall v. Florida Natl Bank, 112 F.2d 380, 381-82 (5th Cir. 1940) (payment to warehouse company for storage charges "was made in the usual course of business and did not constitute a preference voidable under Section 60, sub. b"); In re Macklem, 22 F.2d 426, 427 (D. Md. 1927) (" $[\mathrm{P}]$ ayments of currently inaturing liabilities in such comparatively small amounts as these are probably not preferential payments in any event."); In re Foley, 140 F. 300, 302 (E.D. Pa. 1905) (indicating that a payment of a current expense may not be on account of an antecedent debt); Zelman v. Esher (In re C.S. Mersick \& Co.), 1 Bankr. 599, 601-02 (Bankr. D. Conn. 1979) (rent payments made during month in which they were due were not on account of antecedent debt); 3 COLLIER ON BANKRUPTCY $\| 60.19$, at 852-53 (14th ed. 1974) (advancements upon security for current business operations or expenses does not effect preference); id. \60.23, at 873 (payments on account of current expenses incidental to business operations not generally cousidered preferential); Anderson, In re Iowa Premium Service Co.: When is a Debt Incurred Under 547(c)(2) of the Bankruptcy Code, 17 CREIGHTON L. REv. 1075, 1084 n.56 (1984) ("The 'current expense' rule rested in large part on the recognition that payments for such expenses are not really for an 'antecedent debt' because they do not diminish the estate."); Kaye, Preferences Under the New Bankruptcy Code, 54 AM. BANKR. L.J. 197, 202 (1980) ("Tine underlying rationale of [section 547(c)(2) and the cnrrent expense rule] is the same: no dinimution of the estate, payment not for antecedent debt, and allowing the debtor to stay in business."); Teague, Installment Payments as Voidable Preferences Uncler the Bankruptcy Reform Act of 1978, 53 OKLA. B.J. 2797, 2801-02 (1982) ("There was no exception for normal business or financial affairs transactions under the Act, but courts often allowed an exception ... based on the principle that current expenses were not antecedent debts."). 
subject to attack in bankruptcy. 69

The 1898 Act did not draw a distinction between the avoidability of preferential payments on short-term debt and preferential payments on long-term debt, although as a general matter payments on long-term debt were more likely to be found avoidable than payments on short-term debt. A long-term creditor, such as a bank creditor, might be more likely to have reasonable cause to believe the debtor insolvent than a short-term creditor, such as a trade creditor, because a bank is more likely to monitor the debtor's financial condition. ${ }^{70}$ Not all payments to bank creditors were avoidable, however, because the bank creditor might not have reasonable cause to believe the debtor was insolvent if the financial information it monitored was unreliable or was not available until long after the payment was received. ${ }^{71}$ Thus, under the 1898 Act the avoidability of a payment on a long-term debt depended on the quality and timeliness of the information available to the creditor about the debtor's financial condition. ${ }^{72}$ In most cases a timely payment on a short-term debt, such as

69. See, e.g., Blauvelt v. Walker, 72 F.2d 915 (4th Cir. 1934) (payments of wages not preferences); Ward \& Shulman, In Defense of the Bankruptcy Code's Radical Integration of the Preference Rules Affecting Commercial Financing, 61 WASH. U.L.Q. 1, 19-20 (1983) (wage payments and monthly payments to trade creditors and utility companies are "ordinary and important transactions" that should not be treated as preferences).

70. See W. Hillaman, COMMERCial IOAN DOCUMENTATION 46 (2d ed. 1986) (borrower is commonly required to furnish periodic financial statements).

71. See Farmers Bank v. Julian, 383 F.2d 314, 326 (8th Cir.) (bank creditor did not have reasonable cause to believe debtor was insolvent in part because it had received financial statements from debtor indicating a positive net worth), cert denied, 389 U.S. 1021 (1967). A typical loan agreement covenant would require that the debtor (the "Company") furnish the creditor (the "Bank")

within ninety (90) days after the end of each fiscal year of the Company, copies of balance sheets of the Company .... as at the close of such fiscal year and statements of income and retained earnings of the Company ... for such year, certified by independent public accountants selected by the Company and satisfactory to the Bank.

W. HIIIMAN, supra note 70, at 45; accord COMMITTEE on DEvelorments IN Business FinancING, TERM LOAN HANDBOoK 238 (J. McCann ed. 1983). Quarterly reporting is also usually required within 30 to 60 days after the end of each quarter but quarterly financial statements need only be certified by a principal financial officer of the debtor. Id. at 237; W. HILLMAN, supra note 70, at 45.

72. In many cases, the bank creditor who had information concerning the debtor's finances was found to have received a voidable preference because it had reasonable cause to believe that the debtor was insolvent. See Clower v. First State Bank, 343 F.2d 808, 810 (5th Cir. 1965) (debtor's loan had been extended numerons times); Security-First Nat'l Bank v. Quittner, 176 F.2d 997, 999 (9th Cir. 1949) (debtor had overdrafts and payment on note was overdue); Coombs v. Merchants Bank, 161 F.2d 858, 859-60 (2d Cir. 1947) (evidence showed debtor company was insolvent at time of loan payments); First Wis. Nat'l Bank v. Charness, 73 F.2d 730, 731 (7th Cir. 1934) (bank was aware that payments were made from proceeds of "going out of business" sale conducted by debtor); Pender v. Chatham Phenix Nat'l Bank \& Trust Co., 58 F.2d 968, 970 (2d Cir. 1932) (debtor was six months slow in paying bills, debtor's commercial credit rating had been withdrawn, debtor's bank balance had dwindled, and bank had required payment of notes before due date); Ridge Ave. Bank v. Studheim, 145 F. 798, 800 (3d Cir. 1906) (evidence showed that debtor was insolvent at time of 
trade credit, was not avoidable because trade creditors do not usually monitor the debtor's financial condition to obtain information about the debtor's solvency after the initial decision to deal on credit has been made. The trade creditor might also argue that the payment was not on account of an antecedent debt and hence not preferential under the current expense rule. ${ }^{73}$

\section{B. The Bankruptcy Reform Act of 1978.}

In enacting the Bankruptcy Reform Act of $1978,{ }^{74}$ Congress considered two sets of reform proposals: legislation drafted by the Commission on the Bankruptcy Laws of the United States ${ }^{75}$ (the Commission's Bill) ${ }^{76}$

transfer); Gelbman v. Canton Nat'l Bank, 150 F. Supp. 804, $806-07$ (N.D. Ohio 1957) (debtor had sold merchandise at huge losses, had overdrawn its bank account, had made payments on loan in cash, and had failed to provide financial statements as originally contemplated); Irving Trust $\mathrm{Co}$. v. Textile Banking Co., 3 F. Supp. 816, 817 (S.D.N.Y. 1932) (checks for previous payments had been returned for insufficient funds and bank had made repeated demands for payment), aff'd mem., 65 F.2d 1018 (2d Cir. 1933); Cohen v. Tremont Trust Co. (In re Sternburg), 43 Am. Bankr. Rep. 522 (D. Mass. 1918) (debtor had suspended deposits for more than two weeks, had no other depository accounts, and had asked for larger loans; attachment on debtor's property had just been dissolved).

But other cases have held that payments to a bank creditor could not be avoided because the bank creditor did not have reasonable cause to believe the debtor was insolvent. See, eg., Farmers Bank v. Jutian, 383 F.2d 314,326 (8th Cir.) (bank received debtor's financial statements showing positive net worth and bank extended two additional loans to debtor without perfecting its security interest), cert. denied, 389 U.S. 1021 (1967); Lang v. First Nat'l Bank, 215 F.2d 118, 120-22 (5th Cir. 1954) (bank knew debtor was having difficulty in meeting current obligations, but it also knew debtor had several lucrative jobs near completion); Cusick v. Second Nat'l Bank, 115 F.2d 150, 154 (D.C. Cir. 1940) (debtor's financial statements showed assets in excess of habilities, bank's prior dealings with debtor had been successful, and bank had inquired about debtor's financial situation and received reasonable explanation); In re Frazin, 201 F. 86, 87-89 (2d Cir. 1912) (bank reasonably believed debtor had substantial funds cleposited at time of transfer); Mack v. Bank of Lansing, 396 F. Supp. 935, 942 (W.D. Mich. 1975) (insolvency not apparent since debtor overstated accounts receivable).

73. See supra text accompanying notes 65-69.

74. Act of Nov. 6, 1978, Pub. L. No. 95-598, 92 Stat. 2549. The law had no official short title, but is commonly referred to as the Bankruptcy Reform Act of 1978.

75. The nation's bankruptcy laws, which had been written during the "horse and buggy era of consumer and commercial credit," H.R. REP. No. 595, 95th Cong., 1st Sess. 3, reprinted in 1978 U.S. CODE CONG. \& ADMIN. NEWs 5963, 5965, needed to be updated due to the tremendous explosion in the amount of outstanding consumer credit and the explosion of commercial credit after the adoption of the Umiform Commercial Code. Id. at 3-4, reprinted in 1978 U.S. CODE CONG. \& ADMIN. NEwS at 5964-65.

Even before the Bankruptcy Commission was formally appointed, it was recognized that the 1898 Act had to be revised. In 1966, the National Bankruptcy Conference established the Committee on Coordination of the Bankruptcy Act and the Uniform Commercial Code. Professor Grant Gilmore chaired the committee and it issued its report in 1970. NATIONAL BANKRUPTCY CONFERENCE, REPORT OF THE COMMITTEE ON COORDINATION OF THE BANKRUPTCY ACT AND THE UNIFORM COMMERCIAL CODE (1970), reprinted in 1978 U.S. CODE CONG. \& ADMIN. NEws 6164 [hereinafter NATIONAL BANKRUPTCY CONFERENCE REPORT].

Congress appointed the Commission on the Bankruptcy Laws of the United States to study and recommend revisions of the bankruptcy laws. Act of July 24, 1970, Pub. L. No. 91-354, 84 Stat. 468. 
and legislation drafted by the National Conference of Bankruptcy Judges (the Judges' Bill). 77 The preference provision adopted was virtually identical to the preference provision in H.R. 6,78 a compromise version of the Commission's Bill and the Judges' Bill. ${ }^{79}$ The Commission's Bill and the Judges' Bill both recommended eliminating the 1898 Act's "reasonable cause to believe" requirement, probably the "most litigated question under the preference provision of the 1898 Act." 80 The requirement was

The Commission presented its report to Congress in 1973. REPORT OF THE COMMISSION ON THE BANKRUPTCY LAWS OF THE UNITEd STates, H.R. Doc. No. 137, 93d Cong., 1st Sess. pt. 1 (1973) [hereinafter COMMISSION REPORT]. The report included proposed legislation to replace the 1898 Act. Id. pt. 2.

76. The Commission's Bill was introduced in the House as H.R. 10,792, 93d Cong., 1st Sess. (1973), and in the Senate as S. 4026, 93d Cong., 1st Sess. (1973). It was reintroduced in the House during the 94th Congress as H.R. 31, 94th Cong., 1st Sess. (1975), and in the Senate as S. 236, 94th Cong., 1st Sess. (1975).

77. The Judges' Bill was originally introduced in the House as H.R. 16,643, 93d Cong., $2 d$ Sess. (1974). It was reintroduced in the House as H.R. 32, 94th Cong., 1st Sess. (1975) and was introduced in the Senate as S. 235, 94th Cong., 1st Sess. (1975).

78. The only difference was that the H.R. 6 version did not refer to the "financial affairs" of the debtor in addition to the "business" of the debtor. This language was added to later proposals "[f]or the case of a consumer . . . to include such nonbusiness activities as payment of monthly utility bills." H.R. REP. No. 595, 95th Cong., 1st Sess. 373, reprinted in 1978 U.S. CODE CONG. \& ADMIN. NEws 5963, 6329; S. REP. No. 989, 95th Cong., 2d Sess. 88, reprinted in 1978 U.S. CODE CONG. \& ADMIN. NEws 5787, 5874; Minutes of the Subcomm. on Civil \& Constitutional Rights of the House Comm. on the Judiciary, 95th Cong., Ist Sess. 553 (1977) [hereinafter Mark-Up Minutes of H.R. G] (statement of $\mathrm{Mr}$. Klee) (unpublished transcript held in the Washington and Lee University School of Law Library).

Although the preference provision remained the same, the proposed legislation took various forms before it was finally passed by the House and Senate and signed by the President. During the mark-up of H.R. 6, an amended H.R. 6 was offered as a substitute. The new bill was introduced as H.R. 7330, 95th Cong., 1st Sess. (1977). This bill was further revised in the light of comments from judges, attorneys, and academicians, and a revised version was introduced as H.R. 8200, 95th Cong., 1st Sess. (1977). After further mark-up and various floor amendments, the House passed H.R. 8200, 124 CoNG. REC. 1804 (1978), and the Judiciary Committee issued its report, H.R. REP. No. 595, 95th Cong., 2d Sess., reprinted in 1978 U.S. CODE CONG. \& ADMN. NEws 5963. Meanwhile, the Senate considered its own legislation, S. 2266, 95th Cong., 2d Sess. (1977), which was accompanied by a Senate Judiciary report, S. REP. No. 989, 95th Cong., 2d Sess., reprinted in 1978 U.S. CODE CONG. \& ADMIN. NEws 5787. Before the Senate could act on S. 2266, it considered H.R. 8200, as passed by the House. The Senate amended H.R. 8200 by inserting in its place the text of S. 2266 . 124 CONG. REc. 28,284 (1978). This amended version of H.R. 8200 was passed by the Senate, $i d$. at 30,960 , and sent back to the House. In the House, H.R. 8200 was again amended and then passed. Id. at 32,420. The Senate then considered the bill as amended by the House and passed the bill after further minor amendment. Id. at 34,019. The House concurred in the Senate amendments, id. at 34,145, and the legislation, Public Law No. 95-598, was signed by the President.

79. See Klee, supra note 56 , at $945-46$.

80. D. BAIRD \& T. JACKSON, supra note 13, at 284. See Hearings on S. 2266 and H.R. 8200 Before the Subcomm. on Improvements in Judicial Machinery of the Senate Comm. on the Judiciary, 95th Cong., 1st Sess. 837 (1977) (statement of Charles Horsky, Chairman, National Bankruptcy Conference); see also Hearings on S. 235 and S. 236 Before the Subcomm. on Improvements in Judicial Machinery of the Senate Comm. on the Judiciary, 94th Cong., Ist Sess. pt. II, at 430 (1975) [hereinafter Hearings on S. 235 and S. 236] (statement of Richard Kaufman on behalf of the Na- 
criticized, inter alia, for the stringent burden of proof imposed on the trustee. ${ }^{81}$ The result of the requireinent was frequently "protection, due to lack of proof, for a creclitor who well knew the truth of the situation." 82 The requirement also failed to provide creditors with an indication of what was permissible behavior because courts used a case-by-case approach that produced inconsistent results. ${ }^{83}$

More importantly, cominentators criticized the "reasonable cause to believe" requirement as inconsistent with the principle of equality of distribution of the debtor's assets among its creditors. As one commentator stated:

Logically and theoretically, the knowledge of the recipient of the preference has nothing to do with equality of distribution. Equality is determined by the fact that all creditors are being treated reasonably alike.

So, if two creditors received a payment ... and one had knowledge and one did not of the insolvency of the debtor, that has really no relevancy to equality of treatment. ${ }^{84}$

tional Association of Credit Management) ("[W]e foresee the elimination of much wasteful litigation which presently concerns itself with the dubious issue of the creditor's state of mind ....").

81. See H.R. ReP. No. 595, 95th Cong., 1st Sess. 178, reprinted in 1978 U.S. CODE CoNG. \& ADMIN. NEwS 5963, 6139; S. REP. No. 989, 95th Cong., 2d Sess. 6, reprinted in 1978 U.S. CODE CONG. \& ADMIN. NEWs 5787, 5792; COMMISSION REPORT, supra note 75, pt. 1, at 204; see also Cyr, Setting the Record Straight for a Comprehensive Revision of the Bankruptcy Act of 1898, 49 AM. BANKR. L.J. 99, 166 (1975) ("The vast majority of preferential transfers are never recovered . . . because of the added requirement that the trustee must prove that the transferee had 'reasonable cause to believe that the debtor was insolvent" at the time the transfer was made.").

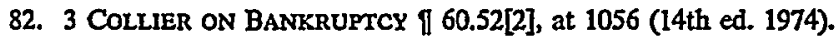

83. See supra note 72; see also 3 ColliER ON BANKRuptcy \l 60.52[2], at 1055 (14th ed. 1974) ("[I]n any consideration of reasonable cause for belief in a debtor's insolvency under $\S 60 \mathrm{~b}$, each ease inust, to a great extent be decided on its own facts."); id. If 60.54[1], at 1071 ("[W] creditor receiving a preference las such reasonable cause to believe [that the debtor is insolvent] must ultimately be determined from the facts of each case."); Clark, Preferences Under the Old and New Bankruptcy Acts, 12 U.C.C. L.J. 154, $156 \mathrm{n.7}$ (1979) (the "reasonable cause to believe" test is applied on a case-by-case basis); Hagedorn, The Survival and Enforcement of the Secured Claim Under the Bankruptcy Reform Act of 1978, 54 AM. BANkR. L.J. 1, 10 (1980) ("[T]he Bankruptcy Act did not specify in what circunstances the reasonable-cause-to-believe fact was to lave been deemed justified, thereby necessitating a case-by-case approaclı to the problem."); Kohn, Preferential Transfers on the Eve of the Bankruptcy Amendments, 2 Prospectus 259, 268 (1968) ("[R]easonable cause to believe the debtor to be insolvent has provided an often crucial factual defense . . . ."); Note, Voidable Preferences: An Analysis of the Proposed Revisions of Section $60 b$ of the Bankruptcy Act, 1974 WIS. L. REV. 481, 485-86 ("Courts . . . have exercised considerable discretion and reached inconsistent results.").

84. Hearings on H.R. 31 and H.K. 32 Before the Subcomm. on Civil and Constitutional Rights of the House Comm. on the Judiciary: Bankruptcy Act Revision, 94th Cong., 2d Sess., pt. 3, at 1855 (1970) [hereinafter Hearings on H.R. 31 and H.R. 32] (statement of Leon Forman on behalf of the National Bankruptcy Conference). See also H.R. REP. No. 595, 95th Cong., 1st Sess. 178, reprinted in 1978 U.S. CODE CONG. \& ADMIN. NEwS 5963, 6139 ("To argue that the creditor's state of mind is an important element of a preference and that creditors should not be required to disgorge what they took in supposed innocence is to ignore the strong bankruptcy policy of equality among credi- 
Predictably, lenders objected to eliminating the "reasonable cause to believe" requirement because it would be unfair to creditors who were unaware of the debtor's insolvency. ${ }^{85}$ In addition, a creditor would have to remit a payment unless it could prove "at considerable expense" that the debtor was not insolvent. 86 The cost of such proof could be "exorbitant" and "would result in higher loan cost[s] to the borrower."87 Nor would the benefit to the other creditors justify the cost to the transfereecreditor, because only a "small portion" of recovered funds would be available to the general unsecured creditors after payment of administrative expenses and distributions to priority claimants. ${ }^{88}$

Despite the lenders' objections, Congress accepted the recommendations of the Commission's Bill and the Judges' Bill ${ }^{89}$ and eliminated the

tors."); COMMISsion REPORT, supra note 75, pt. 1, at 19 ("[T] he requirement that there be a certain state of mind on the part of the favored creditor has [no] rational connection with the objective of this provision, ie, to achieve a more equitable distribution among all of the creditors."); 3 CoLLIER ON BANKRUPTCY $\| 60.52$ [2], at 1056 (14th ed. 1974) (elimination of requirement would remove opportunity for inequitable treatment of creditors where proof of reasonable cause for belief has failed).

The trustee was required to prove not the actral state of the creditor's mind, but whether a reasonable person in the position of the creditor, knowing what the creditor knew about the debtor's financial condition, would have cause to believe that the debtor was insolvent. See Herzog v. Mardan Sec. Bank (In re PRS Prods., Inc.), 574 F.2d 414, 417 (8th Cir. 1978) (debtor's balance sheet provided evidence of insolvency, creditor's records indicated debtor had overdrawn liue of credit on unany occasions, and creditor could have learned of debtor's insolvency from independent sources); Yorke v. Thomas Iseri Produce Co., 418 F.2d 811, 815 (7th Cir. 1969) (debtor was three months late on payments routinely due within month of delivery, creditor knew that debtor was in financial trouble, debtor requested that creditor keep information regarding debtor's financial condition confdential, and atteinpts by creditor to contact debtor proved unsuccessful); Kravetz v. Joange Bldg. Corp., 341 F.2d 561, 562-63 (2d Cir. 1965) (debtor had overdue notes, defaulted in rental payments, quit busmess, and intended to leave stock-in-trade and fixtures on landlord-creditor's premises).

85. Hearings on H.R. 31 and H.R. 32, supra note 84, pt. 4, at 2491 (statement of John Ingraham on behalf of Robert Morris Assocs.) ("In our view it is patently unfair to prejudice a commercial lender who receives a transfer within three months, in good faith, without knowledge of, or reason to believe that, the debtor is insolvent."). Further testimony indicated:

[M]any of our banker friends are disturbed over the removal of the necessity for the trustee to prove that the preferred creditors had reasonable cause to believe that the debtor was insolvent. Perhaps we should also ask whether it is necessary to cause [the preference provision] to bear quite so heavily on one set of creditors-the lenders.

Id. pt. 1, at 397 (statement of Peter Coogan). See also Hearings on S. 235 and S. 236, supra note 80, pt. II, at 457 (statement of Robert Grimmig on behalf of the American Bankers Ass'n); Hearings on H.R. 31 and H.R. 32, supra note 84, pt. 3, at 1749 (same).

86. Hearings on S. 235 and S. 236, supra note 80, pt. II, at 457 (statement of Robert Grimmig); Hearings on H.R. 31 and H.R. 32, supra note 84, pt. 3, at 1749 (same).

87. Hearings on S. 235 and S. 236, supra note 80, pt. $\Pi$, at 457 (statement of Robert Grimmig); Hearings on H.R. 31 and H.R. 32, supra notc 84, pt. 3, at 1749 (same).

88. Hearings on S. 235 and S. 236, supra note 80, pt. II, at 457 (statement of Robert Grimmig); Hearings on H.R. 31 and H.R. 32, supra note 84, pt. 3, at 1749 (same).

89. See CoMmission REPoRT, supra note 75, pt. 1, at 20 ("[T] Commission recommends that ... [t]he requirement that the trustee prove, in order to avoid a preferential transfer, that the 
"reasonable cause to believe" requirement.90 In addition, Congress included a provision creating a presumption that the debtor was insolvent during the preference period. ${ }^{91}$ These statutory requirements meant that a trustee could avoid any payment received by an unsecured creditor from an insolvent debtor on account of an antecedent debt ninety days before bankruptcy. ${ }^{92}$

By eliminating the "reasonable cause to believe" requirement, Congress deliberately shifted from a policy of avoiding only those preferential transfers that were made to creditors who liad reason to know of the debtor's insolvency and may have therefore exerted pressure on the debtor, to a policy of preserving equal distribution, even in the absence of creditor pressure. In recognition of the potential harshness of this shift, Congress ultimately created six exceptions to protect certain payments which, though technically preferential, were believed worthy of protection from avoidance. ${ }^{93}$ One of the exceptions adopted in the 1978 Code

creditor had reasonable cause to believe that the debtor was insolvent at the time of the transfer be eliminated.").

90. H.R. REP. No. 595, 95th Cong., 1st Sess. 178, reprinted in 1978 U.S. CODE CONG. \& ADMIN. NEWS 5963, 6139; S. REP. No. 989, 95th Cong., 2d Sess. 6, reprinted in 1978 U.S. CODE CONG. \& ADMIN. NEWS 5787, 5792. The "reasonable cause to believe" requirement was retained with respect to transfers to insiders between 90 days and one year preceding the filing of the bankruptcy petition. See supra note 29. This requirement was removed in 1984, although this removal may have been unintended. See id.

The Committee on Coordination of the Bankruptcy Act and the Uniform Commercial Code recommended that the National Bankruptcy Conference study whether the "reasonable cause to believe" requirement should be unodified. The Committee's report stated that most of its members felt that "some relaxation of the 'reasonable cause to believe' requirement would be desirable" NATIONAL. BANKRUPTCY CONFERENCE REPORT, supra note 75, reprinted in 1978 U.S. CODE CONG. \& ADMIN. NEws at 6170. The Commission on the Bankruptcy Laws of the United States also recommended that "this requirement for a voidable preference be eliminated." CoMmission REPORT, supra note 75 , pt. 1 , at 20.

91. 11 U.S.C. § 547(f) (1982). The House Report explained the difficulty with the 1898 Act's requirement that the trustee prove that the debtor was insolvent at the time of the transfer:

Given the state of inost debtor's books and records, [proving the debtor insolvent] is nearly impossible. Given the financial condition of nearly all debtors in the three months before bankruptcy, the task is also generally not worth the effort. Rarely is a debtor solvent during the three months before bankruptcy. Thus, the preference section requires the trustee to prove a fact that nearly always exists yet never can be proved with certainty. This factor leads to far fewer preference recoveries than otherwise would be the case. Because of the difficuity of proof, creditors are not deterred from the race of diligence, and the policy of equality is defeated.

H.R. REP. No. 595, 95th Cong., 1st Sess. 178, reprinted in 1978 U.S. CODE CONG. \& ADMIN. NEWS 5963, 6138-39.

92. See Dunham \& Price, supra note 13, at 493 (amendment converted payments during statutory period of presumed insolvency into preferences); see also Fortgang \& King, The 1978 Bankruptcy Code: Some Wrong Policy Decisions, 56 N.Y.U. L. REv. 1148, 1166 (1981) (almost any transfer from debtor to creditor within 90-day period is assumed to be for an antecedent debt).

93. See 11 U.S.C. \$ 547(c) (1982 \& Supp. III 1985); see also CoMMISSION REPORT, supra note 75, pt. 1, at 201 (recommending that certain transfers, such as those of less than $\$ 1000$ value, absolute sales, payments for personal services, and payments for recently incurred utility and inventory 
was, of course, that for a payment of a debt made in the ordinary course of business and within forty-five days of the debt's incurrence.94 The ordinary course of business exception appears to be derived from proposals for protecting from avoidance payments made shortly after the debt's incurrence. It has also been suggested that the exception was derived from the current expense exception recognized under the 1898 Act, ${ }^{95}$ although the legislative history of the 1978 Code does not refer to the current expense rule.

The House and Senate Reports stated that "[t]he purpose of [the forty-five day] exception is to leave undisturbed normal financial relations, because it does not detract from the general policy of the preference section [which is] to discourage unusual action by either the debtor or his creditors during the debtor's shide into bankruptcy."96 Apparently the forty-five day provision was a result of the House Judiciary Committee's judgment that thirty days represented the normal credit term and that an additional period of time should be allowed for a creditor to prepare and send a bill and for the bill to be paid by return mail. A committee staff member noted that rather than attempt to define antecedent debt, ${ }^{97}$

expenses, be excepted from preference attack); id. pt. 2, at $169-70$ n. 6 (payments to employees, trade creditors, and utilities in the ordinary course of business should be protected since creditors receiving payments "ordinarily do not have reasonable cause to believe the debtor insolvent").

94. See 11 U.S.C. \$547(c)(2) (1982), amended by Bankruptcy Amendinents and Federal Judgeship Act of 1984, Pub. L. No. 98-353, § 462(c), 98 Stat. 333, 378.

95. See, eg., Wickham v. Umited Am. Bank (In re Property Leasing \& Management, Inc.), 46 Bankr. 903, 914 (Bankr. E.D. Tenn. 1985); Countryman, supra note 2, at 767-68; Kaye, supra note 68 , at 201-02.

96. H.R. REP. No. 595, 95th Cong., 1st Sess. 373, reprinted in 1978 U.S. Code CoNg. \& ADMN. NEWS 5963, 6329; SEN. REP. NO. 989, 95th Cong., 2d Sess. 88, reprinted in 1978 U.S. CODE CONG. \& ADMIN. NEwS 5787, 5874.

97. The Commission's proposal defined an antecedent debt as "a debt incurred more than five days before a transfer paying or securing the debt." CoMmission REPORT, supra note 75, pt. 2, at 168 (proposed Bankruptcy Act of 1973, \$ 4-607(g)(1)). The definition of antecedent debt excepted debts for personal services, debts for utilities incurred within three months of the petition, and debts for inventory paid for within three months of the delivery of the goods in the ordinary course of the debtor's business. Id. In addition, proposed section 4-607(g)(1)(D) excepted from the definition of antecedent debt "an obligation to transfer ownership arising out of a contract for the sale of property owned by the debtor and in existence either at the date the contract was entered into or at a time more than three months prior to the petition." Id. Ironically, the Commission justified protection of these payinents, although technically payinents on acconnt of an antecedent debt, on the basis of the discarded "reasonable cause to believe" requirement: "employees, trade creditors, and utilities ordinarily do not have reasonable cause to believe the debtor insolvent." Id. at 169-70 n.6 (citing Morris, supra note 64, at 761-65, 767-68). The Commission believed that "antecedent debt" should "be defined so as to exclude certain debts the payinent of which does not infringe substantially on the goals of the preference provisions." Id. pt. 1, at 205.

The National Bankruptcy Conference viewed the Commission's proposal as "much too rigid" and argued in favor of a more flexible standard that would exclude "from the definition of antecedent debt a debt which is intended to be paid or secured contemporaneously with the incurring of it 
[we] decided that what was really important was whether things were going on in the ordinary course of business and, if they were going on within the ordinary course of business, what was a reasonable time? And we took the most extreme ordinary case we could think of where goods ... were ordered on the first of the month and a bill was sent out

if in fact it is paid or secured substantially contemporaneously with the incurring of it." Hearings on H.R. 31 and H.R. 32, supra note 84, app. at 364. The exceptions to the definition of an "antecedent debt" were also criticized for affording special treatment to "special interest group[S] or particular type[s] of claim[s]," contrary to the bankruptcy policy of treating all claimants on a pro rata basis. Id. pt. 3, at 1658 (statement of L.E. Creel, III, on behalf of the Dallas Bar Association). The Conference also criticized the exclusion of all debts for personal services from the definition of an antecedent debt as "much too broad." Id. app. at 364. Finally, the Conference argued that the exception for debts incurred for utilities or inventory within three months of bankruptcy granted too long of a protected period. Id.

The Conference proposed instead that the exception for debts for utilities and inventory be limited to debts incurred within 30 days of payment, when the supplying of the utilities or the delivery of the inventory and the debtor's payment relating to the utilities or inventory were in the ordinary course of business of the debtor and the creditor. Id. The Commission's exceptions from the definition of antecedent debt were also criticized for protecting only the debtor's employees and providers of utilities and inventory, leaving "landlords, unsecured equipment suppliers, and lenders to inquire why only they are now to be subject to the law abeut preferential transfers." Hearings on S. 235 and S. 236, supra note 80, pt. II, at 1041 (statement of Professor Vern Countryman). Other witnesses also complained that unsecured lenders were unfairly prejudiced by the special exceptions to the definition of antecedent debt in the Commission proposal. See Hearings on H.R. 31 and H.R. 32, supra note 84, pt. 4, at 2491 (statement of John Ingraham on behalf of Robert Morris Assocs.).

The preference provision in H.R. 6 departed from the approach taken in the Commission's proposal. Instead of deining antecedent debt and creating exceptions to that definition, section 547(c) of H.R. 6 contained six explicit exceptions to avoidance as a preference, including section $547(c)$ (2) for payment on a debt made within 45 days of the debt's incurrence, if the incurrence of the debt and payment of it were in the ordinary course of business of both the debtor and the creditor, and the payment was made according to ordinary business terms. The transcript of the mark-up minutes of H.R. 6 from the Subcommittee on Civil and Constitutional Rights of the House Committee on the Judiciary also indicates that during the imitial drafting of section $547(\mathrm{c})(2)$, the committee staff was concerned with the protection of ordinary business transactions. "We agrced that the ordinary course of business should be protected. If what you had was something that occurred in the ordinary course and was not truly antecedent, we really shouldn't be upsetting those transfers and causing creditors a lot of trouble." Mark-up Minutes of H.R. 6, supra note 78, at 552 (statement of Mr. Klee). Although the committee staff referred to the protection of "ordinary" transactions, their concept of "ordinary" was obviously limited to short-term transactions because the staff suggested that the payments protected by the ordinary course exception were "not truly antecedent." The "ordinary course of business" language may have been borrowed from the Commission's and the Conference's proposed exceptions from the definition of antecedent debt for payments on debts incurred for utilities or inventory if made within a short time after incurrence and within the ordinary course of business. The Commission proposal excluded from the definition of antecedent debt " $a$ debt for inventory paid for within three months of the delivery of the goods in the ordinary course of the debtor's business" COMMISSION REPORT, supra note 75, pt. 2, at 168 (proposed Bankruptcy Act of $1973, \S 4-607(\mathrm{~g})(\mathrm{I})(\mathrm{C})$ ) (einphasis added).

The National Bankruptcy Conference proposal excluded froin the definition of antecedent debt "a debt for public utilities... paid for not inore than 30 days after it was due where the utilities were supplied and the payment was made in the ordinary course of business of the debtor and the creditor" and "a debt for inventory paid for ... not more than 30 days after delivery where the inventory was supplied and the payment was nade in the ordinary course of business of the debtor and the creditor." Hearings on H.R. 31 and H.R. 32, supra note 84, app. at 363 (emphasis omitted). 
on the last of the month and mailed and the check was mailed back and we figured that was forty-five days and we talked to lawyers about it and businessmen about it and they said that's right. Forty-five days is a fair period. 98

From these comments, and the drafts of prior legislative efforts, it seems that section $547(\mathrm{c})(2)$ obviously was intended to apply to "transactions that take place within a fairly short period,"99 such as those incident to inventory purchases and utility payments. The forty-five day period was chosen as a reasonable period 'because it's a little bit of an extension on the ordinary thirty-day term."100

\section{The 1984 Amendments.}

Beginning in 1979, Congress considered numerous bills proposing changes to the Code. ${ }^{101}$ This process resulted in the 1984 amendinents.

98. Mark-Up Minutes of H.R. 6, supra note 78, at 553 (statement of Mr. Klee).

99. Id. at 562-63. Professor Countryman also embraces this view:

Clearly, Congress intended to limit the exception to the payment of current expenses. If there was an intent to limit the exception also to "trade debt," the draftsmen must have despaired of attempting to define that frequently used but intensely undefined term, and invoked the forty-five day limitation in recognition that most of the trade debt at which they were aiming was short term.

Countryman, supra note 2, at 769 (footnote omitted). Professor Anderson argues that the legislative history indicates that there are three purposes of section 547(c)(2):

Short-term loans may well deserve protection in the same sense that short term [sic] trade credit is protected, since arguably banks making such loans make less inquiry into the debtor's solvency at the time the loan is made and repaid. Further, such short-term loans do represent a true addition to the debtor's estate such that repayment shortly thereafter does not "diminish the estate" on account of an "antecedent debt," as those terms apply to section $547(c)(2)$. Finally, such loans might indeed be more readily made to "marginal" debtors if prompt repayment was protected under section 547(c)(2), and thus would help to keep a struggling debtor out of bankruptcy.

Anderson, supra note 68, at 1093-94. See also Levin, An Introduction to the Trustee's Avoiding Powers, 53 AM. BANKR. L.J. 173, 186 (1979) (section 547(c)(2) was intended to exempt normal trade credit transactions from preferential avoidance); Ward \& Shulman, supra note 69, at $83 \mathrm{n} .268$ (section $547(c)(2)$ was designed to protect "transfers to such 'like-cash' creditors as utilities and trade merchants who bill on a monthly basis").

Several courts have also recognized a distinction between short-term debt and long-term debt. E.g., Marathon Oil Co. v. Flatau (In re Craig Oil Co.), 785 F.2d 1563, 1567 (1ith Cir. 1986) (exception is aimed primarily at ordinary trade credit transactions, short-term obligations which are similar to payment of current expenses); Aguillard v. Bank of Lafayette (In re Bourgeois), 58 Bankr. 657, 659 (Bankr. W.D. La. 1986) ("[P]ayments made by a debtor to employees, suppliers, for utilities and rent, and other similar operating expenses or trade credit transactions, were intended by Congress to be exempt from recovery as preferences.").

100. Mark-Up Minutes of H.R. 6, supra note 78, at 564 (statement of Mr. Levin). See also Levin, supra note 99, at 186 ("Forty-five days was selected as a normal trade credit cycle.").

101. See H.R. 5148, 98th Cong., 2d Sess. (1984); H.R. 1800, 98th Cong., 1st Sess. (1983); S. 445, 98th Cong., 1st Sess. (1983); H.R. 1169, 98th Cong., 1st Sess. (1983); H.R. 1147, 98th Cong., 1st Sess. (1983); H.R. 1085, 98th Cong., 1st Sess. (1983); S. 2000, 97th Cong., 2d Sess. (1982); S. 2000, 97th Cong., 1st Sess. (1981); H.R. 4786, 97th Cong., 1st Sess. (1981); S. 863, 97th Cong., 1st Sess. (1981); H.R. 3705, 97th Cong., 1st Sess. (1981); S. 3259, 96th Cong., 2d Sess. (1980); S. 3023, 96th Cong., 2d Sess. (1980); H.R. 5447, 96th Cong., 1st Sess. (1979); S. 658, 96th Cong., 1st Sess. (1979). 
Several specific problems involving trade debt, commercial paper, and consumer debt had been encountered in the application of the Code and led to two significant changes to the section 547(c) exceptions from avoidance. First, Congress removed section 547(c)(2)'s requirement that the payment to the creditor be made within forty-five days of the date the debt was incurred. 102 Second, Congress added a new exception, section $547(c)(7)$, for small dollar amount transfers made by consumer debtors. This exception provides that the trustee may not avoid a transfer "if, in a case filed by an individual debtor whose debts are primarily consumer debts, the aggregate value of all property that constitutes or is affected by such transfer is less than $\$ 600 . " 103$

Virtually all the complaints inade to Congress regarding the elimination of the forty-five day period were by trade creditors, commercial paper issuers, and consumer lenders. ${ }^{104}$ Trade creditors complained that many normal trade credit payments by a business debtor were avoidable, in the absence of the reasonable cause to believe requirement, and were in many instances not saved from preferential avoidance by the forty-five day rule in section 547(c)(2). Significantly, Congress did not hear from long-term business creditors; they did not complain about the operation of the 1978 Code because most long-term busimess loans are secured.105 In addition, even in the event a long-term creditor required additional security, section 547(c)(2) would not apply because it is limited to "transfers in payment of a debt."

\footnotetext{
Many of the proposals were designed to correct technical problems and unintended consequences of some of the changes made by the 1978 Code. See, eg., S. REP. No. 305, 96th Cong., 1st Sess. 2 (1979). Congress also conducted oversight hearings on the operation of the 1978 Code. See Bankruptcy Reform: Hearings Before the Subcomm. on Courts of the Senate Comm. on the Judiciary, 98th Cong., 1st Sess. (1983) [hereinafter 1983 Bankruptcy Reform Hearings]; Bankruptcy Reform Act of 1978: Hearings Before the Subcomm. on Courts of the Senate Comm. on the Judiciary, 97th Cong., 1st Sess. (1981) [hereinafter 1981 Hearings on Bankruptcy Reform Act]; Preference Section of the Bankruptcy Code, S. 3023: Hearings Before the Subcomm. on Judicial Machinery of the Senate Comm. on the Judiciary, 96th Cong., 2d Sess. (1980) [hereinafter Hearings on S. 3023].

102. Bankruptcy Amendments and Federal Judgeship Act of 1984, Pub. I. No. 98-353, $\S 462(c), 98$ Stat. 333, 378.

103. 11 U.S.C. \& 547 (c)(7) (Supp. III 1985).

104. The hearing testimony before Congress, see supra note 101 , related to problems experienced by these groups.

Some commentators seemed disturbed by the avoidability of regular installment payments, see infra note 124, but only one seemed to argue that all long-term debt (whether or not consuiner installment debt) should be protected under section 547(c)(2). See Nimmer, Security Interests in Bankruptcy: An Overview of Section 547 of the Code, 17 Hous. I. REv. 289, 302 (1980) (purpose of exception is to protect "normal" transactions; this policy basis could support exemption of payments on long-term extensions of credit).

105. See J. MCNEIL \& E. O'LEARY, INTRODUCTON TO COMMERCIAL LENDING 96 (1983); J. Pringle \& R. Harris, Essentials of Managerial FinanCe 462 (1984); J. Weston \& E. BriGham, Essentials of Managerial FinanCE 272 (7th ed. 1985).
} 
Congress eliminated the forty-five day requirement because, contrary to previous assumptions, ${ }^{106}$ the forty-five day period between the date of payment and the date of the incurrence of a debt did not comply with the trade credit practices in most industries. First, more than fifty percent of all industry groups had normal payment periods of forty-five days or longer. ${ }^{107}$ Trade credit periods exceeding forty-five days were common in many seasonal industries including the clothing, toy, and sporting goods industries. ${ }^{108}$

The result was that, in some cases, normal trade credit periods were distorted to fit within the protection of section 547(c)(2).109 It was thought that this distortion of business practices would have one of two effects. Either trade creditors would be unwilling to extend credit for a period longer than forty-five days, causing severe cash flow problems to the buyers and retailers with whom they dealt, 110 or, if credit was extended for longer than forty-five days, the trade creditor would demand terms that would compensate it for the imcreased risk that any payment it received might be avoided and recovered if the debtor subsequently entered a bankruptcy proceeding. ${ }^{111}$

Section 547(c)(2)'s forty-five day requirement was troublesome even in industries with normal trade credit terms of less than forty-five days because debtors encountered considerable difficulty in determining when

106. The drafters assumed that the 45-day period between the date of payment and the date of the incurrence of a debt was compatible with the trade credit practices in most industries. See supra note 98 and accompanying text.

107. See 1981 Hearings on Bankruptcy Reform Act, supra note 101, at 259 (statement of Vyto Gestautas on behalf of the National Ass'n of Credit Management) (citing the National Summary of Domestic Trade Receivables compiled by the Credit Research Foundation, Inc.).

108. Id. at 254 (statement of Irving Sulmeyer, attorney). For instance, sporting goods manufacturers shipped spring and summer sporting goods to retailers in the winter and extended trade credit without interest until the fall, when most retailers would have sufficient cash flow to repay the manufacturers. Id. Trade creditors in industries with long trade credit periods wondered why they should be treated differently than trade creditors in industries where billing periods of 45 days or shorter were common. Id. at 260 (statement of Vyto Gestautas on behalf of the National Ass'n of Credit Management). See also S. REP. No. 65, 98th Cong., 1st Sess. 60 (1983) (the 45-day limitation "places undue burdens upon creditors who receive payment under busimess contracts providing for billing cycles greater than 45 days").

109. Often this change in busmess practices caused "considerable economic sacrifice to the debtor." 1981 Hearings on Bankruptcy Reform Act, supra note 101, at 248 (statement of Leonard Rosen, attorney). Most would agree that " $\mathrm{a}$ bankruptcy law should not be used to require changes in perfectly proper busmess practices or to raise questions as to their validity." Fortgang \& King, supra note 92 , at 1168.

110. See 1981 Hearings on Bankruptcy Reform Act, supra note 101, at 255 (statement of Irving Suimeyer, attorney) ("[T]he greatest suffering and hardship will be imposed upon the small and middle sized retailer who may not be able to pay for merchandise until after the season and after the merchandise has been sold.").

111. See id. at 198 (statement of Vyto Gestautas on behalf of the National Ass'n of Credit Management). 
the debt was deemed to be incurred ${ }^{112}$ and when the payment was deemed to be made. ${ }^{113}$ Court decisions demonstrated that the technical application of the forty-five clay requirement left payments made to many trade creditors unprotected from avoidance. ${ }^{114}$

Short-term creditors, other than those extending trade credit, also encountered difficulties with the operation of section 547(c)(2). Commercial paper issuers objected to the effect section 547(c)(2) bad on the

112. The Bankruptcy Code does not define when a debt is deemed incurred. The determination of the date on which the debt is incurred has proved difficult for many courts. See, eg., Nolden $v$. Van Dyke Seed Co. (In re Gold Coast Seed Co.), 751 F.2d 1118, 1119 (9th Cir. 1985) (debt incurred upon shipment, not when debtor executed agreement to purchase); Nordberg v. Wilcafe, Inc. (In re Chase \& Sanborn Corp.), 51 Bankr. 736, 738 (Bankr. S.D. Fla. 1985) (debt incurred on open account when goods shipped); Harris v. Glo-International Corp. (In re Handsco Distrib., Inc.), 51 Bankr. 700,702 (Bankr. S.D. Ohio 1985) (debt incurred when goods received, rather than when debtor was first obligated to pay pursuant to invoice); Eckles v. Pan Am. Mktg. (In re Balducci Oil Co.), 33 Bankr. 843, 846 (Bankr. D. Colo. 1983) (debt imcurred on date of contract); Richter \& Phillips Jewelers \& Distribs., Inc. v. Dolly Toy Co. (In re Richter \& Phillips Jewelers \& Distribs., Inc.), 31 Bankr. 512, 515 (Bankr. S.D. Ohio 1983) (debt incurred "when the goods are delivered, shipped or identified to the contract, not at the time payment is due or the invoice is sent"); Lansdowne v. Harbor Sec. Bank (In re Bagweli), 29 Bankr. 461, 466 (Bankr. D. Or. 1983) (debt incurred when debtor received goods); Thomas W. Garland, Inc. v. Umion Elec. Co. (In re Thomas W. Garland, Inc.), 19 Bankr. 920, 928 (Bankr. E.D. Mo. 1982) (debt for utility usage imcurred on date utility meter was read).

One commentator notes that:

A variety of rules have been proposed to pinpoint the elusive date, but as yet no firm guideline has emerged. A shibboleth, that a debt is incurred when "the obligation to pay becomes legally binding,' has won widespread acceptance. The phrase is unobjectionable, but adds nothing to the analysis.

Herbert, The Trustee Versus the Trade Creditor: A Critique of Section 547(c)(1), (2) \& (4) of the Bankruptcy Code, 17 U. RICH. L. REV. 667, 681 (1983).

113. See Herbert, supra note 112, at 689. If the transfer is made by check, the transfer could be considered incurred on "the date the check was delivered to the seller, the date the seller initiated the process of bank collection, [or] the date of final payment." Id.

114. See, eg., Grogan v. Liberty Nat'l Life Ins. Co. (In re Advance Glove Mfg. Co.), 761 F.2d 249, 252 (6th Cir. 1985) (payments for insurance premiums avoided because not inade within 45 days of due date); Foreunan Indus., Inc. v. Broadway Sand \& Gravel (In re Foreman Indus., Inc.), 59 Bankr. 145, 154 (Bankr. S.D. Ohio 1986) (payment for gravel made during normal credit term of 30 to 60 days ayoided because not made within 45 days after debt was incurred); Demetralis v. Golden Guernsey, Inc. (In re Demetrahs), 57 Bankr. 278, 284 (Bankr. N.D. Ill. 1986) (payments to creditor for dairy products purchased on open account avoided because not made within 45 days after debt was incurred); Vineyard v. Abel (In re Quality Holstein Leasing, Inc.), 46 Bankr. 70, 7273 (Bankr. N.D. Tex. 1985) (payment for goods avoided because although check for payment delivered within the 45-day period, payment was not deemed transferred until check was honored 47 days after debt was incurred); McLemore v. Ash McNeil Welding Co. (In re Holder \& N. Lumber Co.), 37 Bankr. 265, 266.67 (Bankr. M.D. Tenn. 1983) (payments for services deemed incurred when services were rendered rather than when creditor submitted bill to debtor and were thus ontside the 45-day period); In re Villars, 35 Bankr. 868, 873-74 (Banhr. S.D. Ohio 1983) (payment avoided because the 45-day period began to run when debtor became legally obligated on the debt, contrary to customary practicc); Artesani v. Travco Plastics Co. (In re Super Mkt. Distribs. Corp.), 25 Bankr. $63,65.66$ (Bankr. D. Mass. 1982) (payment avoided even though it was alleged that normally creditor accepted payments within 90 to 120 days of invoice). 
market for commercial paper, ${ }^{115}$ a short-term, unsecured debt obligation typically issued by large corporations.116 Absent the "reasonable cause to believe" requirement, if a commercial paper issuer entered a bankruptcy proceeding within ninety days after repaying a purchaser, the payment would be a preferential transfer and the purchaser might be required to remit the payment as an avoidable preference. ${ }^{117}$ The ouly

115. See Hearings on S. 3023, supra note 101, at 8-17 (statements of George Van Cleave, partner, Goldman, Sachs \& Co., and James Ledinsky, Semior Vice President, A.G. Becker, Inc.).

116. A purchaser, often an institutional investor, buys the issuer's commercial paper for cash in return for the issuer's promise to repay the cash, plus interest, at a fixed time in the future. Commercial paper is necessarily a short-term debt; maturities of commercial paper issues are limited to less than 270 days to avoid registration with the Securities and Exchange Commission. The Securities Act of 1933 exempts from its registration requirements notes with a maturity at the time of issue of not inore than nine months. 15 U.S.C. $\S 77 c(a)(3)$ (1982). Commercial paper is an attractive financing vehicle for many corporations because it is usually issued at an interest rate lower than the rate that would be charged if the corporation borrowed the money froin a bank. Hearings on S. 3023, supra note 101, at 15-16 (statement of James Ledinsky, Senior Vice President, A.G. Becker, Inc.) (companies with top-quality commercial paper ratings borrow, on average, at $1.5 \%$ or more below the cost of alternate sources of short-term funds); $i d$. at 29-30 (statement of Neil Baron, counsel to Standard \& Poor's Corp.) ("The ability to borrow in the commercial paper markets at a cost which is significantly lower than those associated with open bank lines of credit has resulted in extraordinary growth in those markets."); J. PRINGLE \& R. HARRIS, supra note 105, at 668 (the interest rate on commercial paper runs one to one and one-half percent less than the prime lending rate at commercial banks); J. WESTON \& E. BRIGHAM, supra note 105, at 272 (same).

To qualify for such favorable interest rate treatment, however, purchasers of commercial paper must be assured that the debt will be repaid. Thus, only corporations with the highest credit ratings have ready aecess to the commercial paper market. See Hearings on S. 3023, supra note 101, at 13 (statement of George Van Cleave, partner, Goldman, Sachs \& $\mathrm{Co}$.) ("Prime ratings from at least two recognized rating agencies are generally necessary before an issuer can hope to enter this market ..."). Coxporations without such high credit ratings may seek to improve the attractiveness of their commercial paper by backing their promise to repay the purchaser with an irrevocable letter of credit issued by a bank for the benefit of the purchasers of the commercial paper. The bank "in effect lends its credit to the issuer by promising the investor that the bank or insurance company will pay the investor the amount of the commercial paper note if the issuer does not pay." Id. In essence, the bank issuing the letter of credit promises the commercial paper purchaser that if the issuer does not repay the purchaser when the debt is due, the bank will. As a result of the bank's promise, the corporation is able to "piggy-back" on the bank's credit rating and thus gain access to the commercial paper market. Id. at 14 (companies can raise funds at a lower net cost by offering buyers not only their own credit but also the credit of a well-known bank or insurance company).

The credit rating of an issuer's commercial paper might also improve if it was supported by an irrevocable commitment by a bank to lend the issuer money to pay the commercial paper purchasers at inaturity, or by an indemnity bond issued by an insurance company for the benefit of the purchasers of the commercial paper. Id. at 7 (statement of Professor Lawrence King, New York University School of Law). The letter of credit, loan commitment, or indemnity bond "inay be drawn against by the holders of the issuer's commercial paper notes upon the failure of the issuer to pay its cominercial paper notes at maturity." Id.

117. Hearings on S. 3023, supra note 101, at 14 (statement of George Van Cleave, partner, Goldman, Sachs \& $\mathrm{Co}_{\text {.). }}$. The purchaser would not have any recourse against a bank issuing a letter of credit to support the issuer's promise because the bank's liability usually lapses upon payment to the purchaser. Id. at 7 (statement of Professor Lawrence King, New York University School of Law). 
way a purchaser could be assured that the payment would not be avoided was to purchase commercial paper with a maturity of less than forty-five days. The result under the 1978 Code was an artificial shortening of the maturities of commercial paper from as much as $\mathbf{2 7 0}$ days to less than forty-five days ${ }^{118}$ and a decrease in access to the commercial paper market for coinpanies that did not want to issue commercial paper for such a short term. ${ }^{119}$

A further problem noted during this period was the avoidance of preferential payments made by consumer debtors. Section 547 (c)(2) excepted a payment by a consumer debtor from avoidance only if the payment was made and the debt. was incurred in the "ordinary course of ... financial affairs of the debtor and the transferee," and the payment was made according to ordinary business terms, and within forty-five days of

Responding to the 1978 Code's change in the preference provision, rating agencies were forced to base their ratings of commercial paper on the creditworthiness of the commercial paper issuer, rather than inerely on the creditworthiness of the bank issuing the letter of credit. Id. Thus, many companies withont sufficiently high credit ratings found that they could no longer participate in the commercial paper market. See 1981 Hearings on Bankruptcy Reform Act, supra note 101, at 233 (statement of Neil Baron, counsel to Standard \& Poor's Corp.); see also Hearings on S. 3023, supra note 101, at 16 (staternent of James Ledinsky, Senior Vice President, A.G. Becker, Inc.); id. at 22 (statement of Fred Hervey, Chairman and Chief Executive Officer, Circle K Corp.); id. at 25 (statement of Walter Boris, Executive Vice President, Consumers Power $\mathrm{Co}_{\text {.). }}$. Rating agencies based their rating on the bank's creditworthiness ouly if the issuer's counsel furnished a legal opinion that any payments made by the coinpany to the purchaser could not be recovered by a bankruptcy trustee in a subsequent bankruptcy proceeding. See 1981 Hearings on Bankruptcy Reform Act, supra note 101, at 232 (statement of Neil Baron, counsel to Standard \& Poor's Corp.); Hearings on S. 3023, supra note 101, at 30 (same). Counsel gave this opinion only if the commercial paper had a maturity of less than 45 days and the ordinary course of business requirements were also met. Id. (" $[R]$ eputable counsel have differed with respect to the applicability of [the 45-day] exception. One reason is that different uses of commercial paper proceeds could result in different conclusions regarding the 'ordinary conrse' issue.").

118. See Hearings on S. 3023, supra note 101, at 14 (statement of George Van Cleave, partner, Goldman, Sachs \& $C_{0}$.) (the maturity of all commercial paper sold by Goldman Sachs and backed by a letter of credit has been limited to 45 days since the effective date of the 1978 Act); see also Fortgang \& King, supra note 92, at 1170 ("[Section 547(c)(2)] functious to require a period of maturity that in many instances may be unrealistic.").

119. Goldman Sachs was concerned that unless the preference provision was amended, many investors would conclude that "however inuch they should be able to rely on the 45-day exception or other 'solutions' to the problem, it is easier to invest funds elsewhere." Hearings on S. 3023, supra note 101, at 15 (statement of George Van Cleave, partner, Goldman, Sachs \& Co.). See id. at 8 (statement of Professor Lawrence King, New York University School of Law) ("I submit that it was not a purpose of the 1978 Bankruptcy Code to cause valid and established business practices of the commercial paper market to undergo unnecessary change causing additional expense and perhaps loss of access to the commercial paper market merely to comply with a tangentially related bankruptcy law."); see also Fortgang \& Kinß, supra note 92, at 1170 (operation of section 547(c)(2) may make badly needed capital unavailable to many corporations). Additionally, the legal "opinions and structural acrobatics" resulted in "substantially higher costs to issuers, dealers, investunent bankers and persons providing third party supports." 1981 Elearings on Bankruptcy Reform Act, supra note 101, at 233 (statement of Neil Baron, counsel to Standard \& Poor's Corp.). 
the date the debt was incurred. ${ }^{120}$ Creditors coinplained that regular payments received from consumer debtors on long-term installment obligations were avoidable even though the creditors may not have had reasonable cause to believe that the debtor was insolvent. Solne creditors receiving payments from consumer debtors on long-term installment obligations attempted to assert entitlement to section 547(c)(2)'s protection by arguing that the date the debt was "incurred," i.e., the date the fortyfive day period began to run, was the date the loan payment was due. The United States Court of Appeals for the Seventh Circuit rejected this argument in Barash v. Public Finance Corp. ${ }^{121}$ and held that regular installment payments by consumer debtors to undersecured creditors were avoidable as preferences because the debt for the principal amount of the loan was incurred on the date of the loan, rather than on the date each installment was due. ${ }^{122}$ Most other courts ${ }^{123}$ and commentators ${ }^{124}$ agreed with this result.

120. 11 U.S.C. \$ 547(c)(2) (1982), amended by Bankruptcy Amendments and Federal Judgeship Act of 1984, Pub. L. No. 98-353, §462(c), 98 Stat. 333, 378.

121. 658 F.2d 504 (7th Cir. 1981).

122. Id. at 512 .

123. See, eg., Wickham v. United Am. Bank (In re Property Leasing \& Managennent, Inc.), 46 Bankr. 903, 913-14 (Bankr. E.D. Tenn. 1985); Tidwell v. Merchants \& Farmers Bank (In re Deinpster), 59 Bankr. 453, 459 (Bankr. M.D. Ga. 1984); Pippin v. John Deere Co. (In re Pippin), 46 Bankr. 281, 283-84 (Bankr. W.D. La. 1984); Rabin v. Equibank (In re Faller), 42 Bankr. 593, 594-95 (Bankr. N.D. Ohio 1984); Schmitt v. Equibank (In re R.A. Beck Builder, Inc.), 34 Bankr. 888, 892 (Bankr. W.D. Pa. 1983); Sanborn v. Bangor Fed. Credit Union (In re Sanborn), 29 Bankr. 655, 65758 (Bankr. D. Me. 1983); Grant v. Blazer Fin. Servs. (In re Head), 26 Bankr. 578, 580 (Bankr. M.D. Fla. 1983); Whitlock v. Max Goodman \& Sons Realty, Inc. (In re Goodınan Indus., Inc.), 21 Bankr. 512, 521-22 (Bankr. D. Mass. 1982); Grant v. Jacksonville Postal Credit Union (In re Anders), 20 Bankr. 468, 469 (Bankr. M.D. Fla. 1982); Ashbier v. General Fin. Co. (In re Bryant), 20 Bankr. 314, 316 (Bankr. W.D. Ky. 1982); Spence v. Lansing Automakers Fed. Credit Union (In re Satterla), 15 Bankr. 166, 168 (Bankr. W.D. Mich. 1981); Paskin v. First Nat'l Bank (In re Donny), 11 Bankr. 451, $452-53$ (Bankr. W.D. Wis. 1981); Kampf v. Postal Finance (In re Keeling), 11 Bankr. 361, 36263 (Bankr. D. Minn. 1981); Belfance v. BancOhio/National Bank (In re McCormick), 5 Bankr. 726, 731 (Bankr. N.D. Ohio 1980); Weill v. Southern Credit Union (In re Bowen), 3 Bankr. 617, 619 (Bankr. E.D. Tenn. 1980). But see Berstein v. RJL Leasing (In re White River Corp.), 799 F.2d 631, 633 (10th Cir. 1986); Lang v. Advance Loan Co. (In re Graves), 45 Bankr. 858, 860, 865 (E.D. Cal. 1985).

124. See, eg., D. BAIRD \& T. JACKSON, supra note 13, at 317; 4 COLLIER ON BANKRUPTCY If 547.38, at 547-125 (15th ed. 1985); P. MURPHY, CREDITOR's RIGHTS IN BANKRUPTCY $§ 10.15$ (Supp. 1985); Anderson, supra note 68, at 1093-94; Ward \& Shulman, supra note 69, at 83 n.268; Comment, Preferences and Setoffs: Sections 547 and 553, 2 BANKR. DEv. J. 49, 58 (1985). But cf. Kaye, supra note 68, at 204-05 (arguing that section 547(c)(2) "requires some rethinking" and suggesting that perhaps different provisions are needed for different types of debt); Nimmer, supra note 104, at 302 (section 547(c)(2) designed to protect "normal" transactions, which could include longterm extensions of credit); Tait \& Williams, Bankruptcy Preference Laws: The Scope of Section $547(c)(2), 99$ BANKING L.J. 55, 60.61 (1982) (using an analogy to section 547(a)(4) relating to when a debt for taxes is incurred and urging that section $547(\mathrm{c})(2)$ protection be extended to payments to installinent lenders). 
After the rejection of the creditor's argument in Barash that a consumer debt was incurred when the installment payment was due rather than when the loan funds were advanced, creditors argued that payments inade by business debtors for the interest portion of a long-term debt were protected by the forty-five day exception because the debt for interest was incurred each day as the interest accrued. The Umited States Court of Appeals for the Eighth Circuit sitting en banc accepted this argument in Iowa Premium Service Co. v. First National Bank of St. Louis (In re Iowa Premium Service Co.), 125 but the decision has not been uniformly followed outside the Eighth Circuit. ${ }^{126}$

Consumer creditors also asserted that avoiding payments made by consumer debtors on long-term installment obligations did not further equality of distribution of the debtor's estate because the additional sums recovered by the trustee were usually sufficient only to offset the administrative expenses associated with recovery. ${ }^{127}$ The net result was that the

125. 695 F.2d 1109, 1112 (8th Cir. 1982) (en banc). Significantly, the parties stipulated that the bank creditor's demand note was incurred in the ordinary course of the debtor's and creditor's businesses. Id. at 110. The court's holding may have been conditioned on the fact that the debtor was entitled to repay the loan without penalty. It could be argued that if the loan contained a prepayment penalty, interest in the amount of the penalty would be deemed incurred on the date the loan was inade. See Lang v. Advance Loan Co. (In re Graves), 45 Bankr. 858, 860 (E.D. Cal. 1985).

Numerous courts followed Iowa Premium and protected interest payments from avoidance if made within 45 days of the date the interest accrued. See, eg., id; Robbins v. Production Credit Ass'n (In re Walkington), 62 Bankr. 989, 994 (Bankr. W.D. Mich. 1986); Campbell v. Ford Motor Credit, Inc. (In re Emie Causey Ford, Inc.), 57 Bankr. 78, 80 (Bankr. D.S.C. 1985); Rabì v. Equibank (In re Faller), 42 Bankr. 593, 595 (Bankr. N.D. Ohio 1984); Schmitt v. Equibank (In re R.A. Beck Builder, Inc.), 34 Bankr. 888, 893 (Bankr. W.D. Pa. 1983).

It was suggested in 1980 that the "Code does not specify whether interest, payable less often than every forty-five days, is an obligation incurred on the date it is payable or incurred as it accrues (i.e., on a daily basis) with protection only for the forty-five day period preceding payment." American Bar Association Committec on Developments in Business Financing, Structuring and Documenting Business Financing Transactions Under the Federal Bankruptcy Code of 1978, 35 Bus. Law. 1645,1649 (1980).

126. See, eg., Lingley v. Stuart Shaines, Inc. (In re Acme-Dunham Inc.), 50 Bankr. 734, 741 (D). Me. 1985) (obligation to pay interest "arises when the debtor gets a property interest in the consideration exchanged" in loan transaction); Henderson v. Allred (In re Western World Funding, Inc.), 54 Bankr. 470, 480 (Bankr. D. Nev. 1985) ("[D]ebt for interest is incurred when the debtor obtains the funds, even if at that time the obligation is unmatured and contingent."); see also Anderson, supra note 68 , at $1080-88$.

127. See S. REP. No. 65 , supra note 108 , at 14 ("[T]he administrative expense of these collections, particularly in individual proceedings, results in very little being distributed to creditors."); S. REP. No. 446, 97th Cong., 2d Sess. 24 (1982) (same); 1983 Bankruptcy Reform Hearings, supra note 101, at 229 (statenent of Eldon Hoekstra, Secretary, Credit Union National Ass'n, Inc.) ("[C]redit unions report that the majority of the funds recovered go to the cost of administration rather than redistribution among creditors."); id. at 124-25 (statement of Robert Evans, Senior Vice President and General Counsel, National Consumer Finance Ass'n) ("Other creditors are not benefited by this section since little if any of the recovered payments are left to distribute after the administrative costs and collection costs are paid."); 1981 Hearings on Bankruptcy Reform Act, supra note 101, at 69 
debtor's estate was not enhanced for the benefit of the creditors. ${ }^{128}$

Four types of solutions, in addition to the proposal to eliminate the forty-five day requirement, ${ }^{129}$ were proposed to resolve these perceived problems with the application of the preference provision. ${ }^{130}$ First, in $1981,{ }^{131} 1982,{ }^{132}$ and $1983^{133}$ bills were introduced to remsert the "reasonable cause to believe" requirement as an element of a preferential transfer under section 547(b). Reinsertion of this requirement would have largely eliminated the alleged problems with the application of the preference provision because most trade creditors, commercial paper issuers, and consumer lenders would not have reasonable cause to believe the debtor was insolvent. ${ }^{134}$ This conclusion would be especially true in those instances where the issuer's promise to repay the commercial paper purchaser was backed by a letter of credit issued by a bank. It would be unusual for the purchaser to independently momitor the financial condition of the issuer, because the purchaser could instead rely on the bank's

(statement of Claude Rice, Alvin Wiese, Jr., and Jonathan Landers) ("[A]lthough the provision theoretically promotes equality, in fact, little actually trickles down to nonpreferred creditors.").

128. It was also argued that the goal of preventing last minute pressure by one creditor to the prejudice of other creditors was not served because a creditor receiving a timely payment in the ordinary course of business had no reason to pressure the debtor and had no knowledge of the debtor's financial difficulties. See 1981 Hearings on Bankruptcy Reform Act, supra note 101, at 69

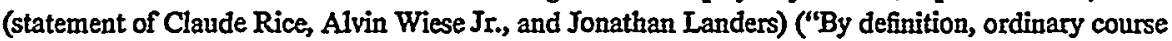
payments do not involve creditor pressure of a type which is deterred by the preference section.").

129. S. 445, 98th Cong., 1st Sess. \$211(b) (1983). The explanation for this change was that the 45-day limitation "places undue burdens upon creditors who receive payment under business contracts providing for billing cycles greater than 45 days." S. REP. No. 65 , supra note 108 , at 60 .

130. It was also suggested that section 547 (c)(2) be amended to provide that a payment be excepted from avoidance if made shortly after the date the debt was due. Various time periods were suggested, ranging from five to forty-five days. The National Association of Credit Management proposed that a payment by a debtor to a creditor be excepted from preferential avoidance if "made on or before the date when the indebtedness became due or within 45 days thereafter, and made according to terms of credit extended by the transferee at the time the indebtedness was created." 1981 Hearings on Bankruptcy Reform Act, supra note 101, at 261 (statement of Vyto Gestautus, on behalf of the National Ass'n of Credit Management); accord id. at 249 (statement of Leonard Rosen, attorney). A fifteen-day period, $i d$. at 255 (statement of Irving Sulmeyer, attorney), and a five-day period, Fortgang \& King, supra note 92, at 1171, were also proposed.

131. S. 2000, 97th Cong., 1st Sess. $\$ 10$ (1981); H.R. 4786, 97th Cong., 1st Sess. $§ 11$ (1981).

132. S. 2000 , 97th Cong., $2 d$ Sess. $\$ 11$ (1982).

133. H.R. 1800, 98th Cong., 1st Sess. § 111 (1983); S. 445, 98th Cong., 1st Sess. § 211(a) (1983); F.R. 1169, 98th Cong., 1st Sess. $\S 11$ (1983); H.R. 1085, 98th Cong., 1st Sess. $§ 11$ (1983).

134. The 1898 Act did not draw a distinction between the avoidability of preferential payments on short-term debt and the avoidability of preferential payments on long-term debt, although as a general matter payments on short-term debt were less likely to be found avoidable. In most cases a timely payment on short-term debt, such as trade credit, was not avoidable because a trade creditor was unikely to have reasonable cause to believe that the debtor was insolvent. See Dunham \& Price, supra note 13, at 493. Trade credit is short-term credit extended by a seller in connection with the sale of goods or the provision of services. See Countryman, supra note 2, at 769. Trade creditors do not usually monitor the debtor's financial condition to obtain information about the debtor's solvency after the initial decision to deal on credit has been made. 
promise to pay if the issuer did not. The conclusion would also be true as to consumer lenders who also do not monitor a consumer's financial condition after making the initial decision to lend. Finally, the "reasonable cause to believe" requirement would also serve to protect from avoidance paynents to creditors on long-term debt, made after the expiration of the protected forty-five day period, if the trustee was unable to prove that the creditor had reasonable cause to believe the debtor was insolvent at the time of the payment.13s

A second legislative proposal was directed to the particular problems of commercial paper purchasers. ${ }^{136}$ A special exception for payments nlade by a commercial paper issuer to the purchaser was proposed.137 The National Bankruptcy Conference objected to this "piecemeal" approach to the problems created by the 1978 Code's radical revision of the preference provision. ${ }^{138}$

The third proposal addressed the problems expressed by consumer installment lenders. It proposed an exception that would insulate a payment from preferential avoidance if the aggregate value of all property constituting or affected by such transfer was less than $\$ 250$ in a Chapter 7 or Chapter 13 case or less the $\$ 750$ in a Chapter 11 case. ${ }^{139}$ A modified version of this proposal, the current section 547(c)(7), was contained in H.R. 5174, the bill that was eventually passed as the 1984 amendnients. 140

135. See supra notes 70-72 and accompanying text.

136. H.R. 5148, 98th Cong., 2d Sess. (1984); S. 445, 98th Cong., 1st Sess. (1983); S. 3023, 96th Cong., 2d Sess. (1980).

137. For instance, H.R. 5148, 98th Cong., $2 d$ Sess. (1984) would have amended section 547 (c) by adding the following:

(c) The trustee may not avoid under this section a transfer

...

(7) to or for the benefit of a creditor to the extent such transfer was made to such creditor in payment of a debt evidenced by a note issued by the debtor prior to the commencement of the case, and payment of which was supported from the time of its issuance until such transfer by an irrevocable letter of credit, commitment to lend funds, or bond of indemnity issued by a credit guarantor in the ordinary course of its business, and without regard to whether such transfer gives rise to a secured or unsecured claim against the debtor in favor of the transferor.

138. 1981 Hearings on Bankruptcy Reform Act, supra note 101, at 250 (statement of National Bankruptcy Conference).

139. H.R. 1147, 98th Cong., 1st Sess. $\$ 9$ (1983).

140. Congress had considered similar "small transfer" exceptions to preferential avoidance during the discussions leading to the passage of the 1978 Code. The Commission's Bill created an exception for transfers of an aggregate value of less than $\$ 1000$ to a noninside creditor. See CommisSION REPORT, supra note 75, pt. 2, at 166 (proposed Bankruptcy Act of 1973, § 4607(b)(1)). The Commission reasoned that "[r]elatively small preferences do not seriously impinge on the goals of equality of treatment, avoidance of the grab-bag effect, and prevention of unwise extension of credit. In addition, the expense of recovery is often disproportionate to the benefit to creditors." Id. pt. 1, at 206. Judge Cyr criticized this explanation, arguing that the blanket exemption "is unrelated to the cost of setting aside any given transfer which may require no more than a mere demand." Cyr, 
The culmination of the discussions regarding possible modification of section 547, as it was enacted in the 1978 Code, was H.R. 5174. ${ }^{141}$ H.R. 5174 proposed only one change to section 547(c): the introduction of section 547(c)(7), relating to payments by consumer debtors. ${ }^{142}$ The bill was hastily considered in the House because of the urgency of the jurisdictional crisis facing the bankruptcy court system ${ }^{143}$ and was passed by the House after the jurisdictional provisions of the bill were amended. ${ }^{144}$

The Senate then began consideration of the bill. Senator Thurmond introduced an amendment in the nature of a substitute for the bill passed in the House. ${ }^{145}$ Senator Thurmond noted that although portions of his amendment were not included in the House bill, the changes did "have broad support in the Senate."146 The amendment contained four distinct provisions affecting the preference provision of the 1978 Code and addressing problems with its operation that had previously been considered by the House and Senate. First, Senator Thurmond proposed to amend

Setting the Record Straight for a Comprehensive Revision of the Bankruptcy Act of 1898, AM. BANXR. L.J. 99, $166 \mathrm{n} .242$ (1975). The decision to attack a particular transfer as a preference should be left to the discretion of the trustee. Id. Similarly, the report of the National Bankruptcy Conference suggested that Congress abolish the "reasonable cause to behieve" requirement with respect to transfers in excess of a certain dollar amount, "while smaller transfers ... [should] be immunized from attack under § 60." NATIONAL BANKRUPTCY CONFERENCE REPORT, supra note 75, reprinted in 1978 U.S. CODE CONG. \& ADMIN. NEws 6164, 6170.

In the Judges' Bill, however, transfers aggregating less than $\$ 1000$ to noninsiders were not excepted from avoidance as preferences. See Hearings on H.R. 31 and H.R. 32 Before the Subcomm. on Civil and Constitutional Rights of the House Comm. on the Judiciary, 94th Cong., 1st \& 2d Sess. app. at 177 (1975-70). The Bankraptcy Conference proposal retained the small transaction exception, but limited it to transfers to noninside creditors where the aggregate value of all property so transferred to that creditor amounted to less than \$500. See id. app. at 362 (Bankruptcy Act of 1975, prepared by the National Bankruptcy Conference). The Conference argued that the Commission's proposal would prevent the trustee from recovering preferences of less than $\$ 1000$ even when recovery could be had without incurring significant expense. See id. app. at 363. H.R. 6 and the resulting Bankruptcy Reform Act of 1978 did not, however, include an exception for small-dollar amount transactions.

141. H.R. 5174, 98th Cong., 2d Sess. (1984).

142. $I d$.

143. See supra note 54. The procedural posture of the bill prevented consideration of more than one amendment, 130 CoNG. REC. H1796 (daily ed. Mar. 21, 1984), although this limitation was controversial. One congressman stated that substantive bankruptcy revision needed to be considered indepeudently of jurisdictional issues; "The package presented to this body today holds bankruptcy law reform measures hostage to court-restructuring legislation." Id. at H1802 (statement of Rep. Porter). Other representatives argued that the changes in the preference provision were in accord with "issues that we dealt with in our original H.R. 1800 and which were worked out in the compromise." Id. at H1810 (statement of Rep. Synar); accord id. at H1826 (statement of Rep. Matsui).

144. Id. at H1854.

145. Id. at S6081 (daily ed. May 21, 1984). The text of the amendment (No. 3083) is set forth id. at $\mathrm{S} 6107-27$.

146. Id. at $\mathrm{S} 6083$. 
section 547(b) to reinsert the "reasonable cause to believe" requirement as an elenent of a preferential transfer. ${ }^{147}$ This proposal was withdrawn by Senator Thurmond prior to the amendment's passage in the Senate, ${ }^{148}$ however, apparently in order to gain Senator Metzenbaum's support for the remainder of Senator Thurmond's proposals. ${ }^{149}$

The second proposed change to section 547 involved amending section 547(c)(2) to reinove the forty-five day requirement. ${ }^{150}$ This cliange had previously been endorsed by the Senate when it passed S. 445 in 1983.151 The Senate Report accompanying that bill explained that the change was necessary because the forty-five day limitation "places undue burdens upon creditors who receive payment under business contracts providing for billing cycles greater than 45 days."152

A third proposal involved adding section 547(c)(8) to protect payments to commercial paper purchasers from avoidance, ${ }^{153}$ but this proposal was also withdrawn prior to the amendinent's passage. ${ }^{154}$ One possible explanation for the withdrawal of proposed section 547(c)(8) is that elimination of the forty-five day provision from section 547(c)(2) resolved the commercial paper problem and made a special section protecting payments to commercial paper purchasers unnecessary. ${ }^{155}$

147. Id. at $\mathrm{S} 6122$. This suggestion had been previously considered in Congress. See supra notes 131-33 and accompanying text.

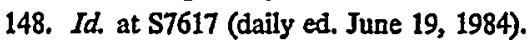

149. Id. (statement of Sen. Thurmond).

150. Id. at $\mathbf{S 6 1 2 2}$ (daily ed. May 21, 1984).

151. Id. at $\$ 5388$ (daily ed. Apr. 27, 1983).

152. S. REP. No. 65 , supra note 108 , at 60 .

153. Senator Thurmond's amendment would have amended section $547(c)$ by adding subparagraph (8), under which the trustee could not avoid a transfer

to or for the benefit of a creditor to the extent such transfer was made to such creditor by a credit guarantor in payment of a debt evidenced by a note or bond issued by the debtor prior to the commencement of the case and in accordance with the terms of the debtor's credit guaranty agreement with the credit guarantor, and payment of which was supported from time of its issuance until such transfer by an irrevocable letter of credit, irrevocable commitment to lend funds, irrevocable note purchase agreement, or a bond of indemnity issued by a credit guarantor in the ordinary course of its business.

Id. at $\mathrm{S} 6127$ (daily ed. May 21, 1984).

The section was substantially identical to that in S. 445, introduced in 1983, which, as passed by the Senate, protected transfers inade to the commercial paper purchaser by the credit guarantor, rather than transfers made to the purchaser by the issuer of the commercial paper. See supra notes 136-37.

154. See Countryman, supra note 2 , at 772.

155. A discussion on the Senate fleor between Senators Dole and DeConcini regarding the Conference Report on the bill indicates that they believed that the elimination of the 45-day requirement would "relieve buyers of commercial paper with maturities in excess of 45 days of the concen that repayments of such paper at maturity might be considered as preferential transfers," and that "companies that have a need for short-term funds, and investors who wish to purchase short-term obligations, would botll be acting in their respective 'ordinary course of business or financial affairs' " in 
The final section of Senator Thurmond's amendment affecting section 547(c) was the addition of section $547(\mathrm{c})(7)$ to protect certain payments by consumer debtors from preferential avoidance. ${ }^{156}$ The proposed addition was identical to that already approved in the House version of H.R. 5174. The Senate passed H.R. 5174,157 as changed by Senator Thurmond's amendment, adding section 547(c)(7) to the 1978 Code to protect some payments by consumer debtors from avoidance and eliminating the forty-five day provision from section $547(\mathrm{c})(2)$.

The Senate insisted on its version of the bill and asked for a conference with the House. ${ }^{158}$ The House agreed to the conference and the conference report was submitted on June 29, 1984.159 The report did not include a joimt explanatory statement of the bill, but only the text of the bill as agreed to in conference. The conference version of the bill was identical to the version passed by the Senate as it related to section $547 .{ }^{160}$ The conference bill was accepted by both the Senate and the House $^{161}$ and signed by the President.

Although the legislative history is not conclusive, it is possible to assert that the changes made by the 1984 amendments to the preference provision were made merely in response to particular concerns of various creditor groups. Thus, removal of the forty-five day provision responded to problems encountered by trade creditors ${ }^{162}$ and commercial paper purchasers ${ }^{163}$ who asserted that the arbitrary forty-five day limitation was not consistent with regular short-term extensions of credit and resulted in the distortion of normal business practices to fit within the exception. Further, the addition of section $547(\mathrm{c})(7)$ to protect certain small dollar amount transfers by consumer debtors responded to the problems encountered by lenders to consumers following elimination of the "reasonable cause to behieve" requirement. 164

dealing with each other in the commercial paper market. 130 CONG. REC. $\$ 8897$ (daily ed. June 29, 1984, pt. II). See also Dunham \& Price, supra note 13, at 497-99.

156. Senator Thurmond's amendment proposed the addition of section $547(\mathrm{c})(7)$ to except from preferential avoidance a transfer "if, in a case filed by an individual debtor whose debts are primarily consumer debts, the aggregate value of all property that constitutes or is affected by such transfer is less than \$600." 130 CONG. REC. S6114 (daily ed. May 21, 1984).

157. Id. at $\$ 7625$ (daily ed. June 19, 1984).

158. Id.

159. H.R. CONF. REP. No. 882, 98th Cong., 2d Sess., reprinted in 1984 U.S. CODE CONG. \& ADMIN. NEWS 576.

160. 130 CoNG. REc. $\$ 8887$ (daily ed. June 29,1984 , pt. II) (statement of Sen. Thurmond); id. at H7489 (daily ed. June 29, 1984, pt. I) (statement of Rep. Rodino).

161. Id. at \$8900, H7500 (daily ed. June 29, 1984, pt. II).

162. See supre text accompanying notes 106-14.

163. See supra text accompanying notes 115-19.

164. See supra text accompanying notes 120-24. 
Some commentators have suggested that the removal of the fortyfive day provision from the ordinary course of business exception should be read as extending the exception's protection to payments on long-term debt because the "legislative history contains no express statement which limits 547(c)(2) to short-tern debt."165 The contrary inference, however, seems more persuasive - that is, the absence of any clear indication that Congress intended to expand section $547(\mathrm{c})(2)$ protection to long-term debt justifies an inference that there was no such intent. Furthernoore, because no creditors complained during the hearings conducted on the operation of the 1978 Code that the avoidance of payments on long-term debt by business debtors was unfair, ${ }^{166}$ it is unlikely that Congress considered the avoidability of such payments a problem that it should address. Nor is there any indication that Congress intended, by eliminating the forty-five day requirement, to narrow the objective of the preference provision from that of preserving equality of distribution to that of preventing inequality resulting from impermissible creditor pressure apphed by a creditor hoping to obtain more favorable treatment than it would otherwise receive in the debtor's bankruptcy proceeding. The most obvious indication that Congress did not wish to return to a concept of avoiding only those payments that might be the result of creditor pressures was its decision not to return to the "reasonable cause to beheve" requirement as an element of a preferential transfer. Long-term creditors lost the protection of the "reasonable cause to believe" requirement as a result of a deliberate policy choice by Congress in the 1978 Code. It appears unreasonable to suggest that Congress intended to overturn that choice in the 1984 amendments witliout significant discussion, ${ }^{167}$ particularly when the discussion that did accoinpany the amendment of section $547(\mathrm{c})(2)$ is consistent with interpreting the section to protect only short-term debt.

\section{RECONCIIING the ORdINARY COURSE OF BusIness EXCEPTION WITH THE POLICIES OF THE Preferrence Provision}

Although the legislative history of the ordinary course of busimess exception plausibly supports, or at least is not imconsistent with, an interpretation of section 547(c)(2) excluding long-term debt from its coverage,

165. DeSimone, supra note 13 , at 129.

166. See supra note 105 and accompanying text.

167. See Aguillard v. Bank of Lafayette (In re Bourgeois), 58 Bankr. 657, 659-60 (Bankr. W.D. La. 1986) ("It also seems unlikely that Congress intended to make a sweeping change in the ordinary course exception, because of the lack of debate and legislative history accompanying the amendment."). 
that history is obviously inconclusive. Examination of the policies of the preference provision and the ordinary course of business exception is thus critical to a proper determination of the exception's scope.

The principal objective of the preference provision is to "facilitate the prime bankruptcy policy of equality of distribution among creditors of the debtor."168 When a debtor becomes insolvent, a transfer to a creditor whose claim is not fully secured necessarily impairs the claims of the debtor's other unsecured and undersecured creditors. ${ }^{169}$ The trustee's power to avoid preferential transfers only partially prevents the resulting unequal treatment of creditors because tlie power in most cases extends only to transfers made during the ninety day period preceding the filing of the bankruptcy petition and does not reacli transfers previously made by an insolvent debtor. ${ }^{170}$

It has been suggested that section 547 (c)(2), as originally enacted, was justified because it was not inconsistent with the goal of equal distribution. The argument is that payments of short-term debt do not deplete the debtor's estate because the recent extension of credit provides offsetting value to the estate. ${ }^{171}$ The court in Bourgeois and at least one commentator have relied on this "depletion of the estate" rationale to argue that section 547(c)(2), as amended, should not be read to cover payments on long-term debt. ${ }^{172}$ This argument, although superficially attractive, is

168. H.R. REP. No. 595, 95th Cong., 1st Sess. 178, reprinted in 1978 U.S. CODE CONG. \& ADMIN. NEws 5963, 6138. See also Palmer Clay Prods. Co. v. Brown, 297 U.S. 227, 229 (1936); D. BAIRD \& T. JACKSON, supra note 13, at 281; 4 CoLLIER ON BANKRUPTCY If 547.03, at 547-20 (15th ed. 1985); McCoid, Bankruptcy, Preferences, and Efficiency: An Expression of Doubt, 67 VA. L. REV. 249, 260 (1981); Seligson, Preferences Under the Bankruptcy Act, 15 VAND. L. REV. 115, 115 (1961).

Of course, the equality of distribution principle may be more accurately claracterized as a "policy of preserving classes and of preserving equality within classes," Countryman, supra note 2, at 748, in recognition of the fact that creditors with perfected security interests are preferred over unsecured creditors and priority claimants are preferred over nonpriority claimants.

169. See McCoid, supra note 168 , at 260.

170. The trustee is empowered only to avoid preferential transfers made 90 or fewer days before the filing of the bankruptcy petition, 11 U.S.C. $\$ 547(\mathrm{~b})(4)(A)$ (Supp. III 1985), or less than one year before the filing of the petition if the transfer is to an insider. Id. $\S 547(b)(4)(B)$.

171. See Lingley v. Stuart Slaines, Inc. (In re Acme-Dunham Inc.), 50 Bankr. 734, 740 (D. Me. 1985); Wickham v. United Am. Bank (In re Property Leasing \& Managenent, Inc.), 46 Bankr. 903, 914 (Bankr. E.D. Tenn. 1985); Herbert, supra note 13, at 217; Kaye, supra note 68, at $201-02$.

172. See Aguillard v. Bank of Lafayette (In re Bourgeois), 58 Bankr. 657, 660 (Bankr. W.D. La.

1986). Professor Duncan makes the argument as follows:

[U]nlike the case of short-term financing of goods and services, in which value is given to the financially distressed debtor during his or her slide into bankruptcy, there is no offsetting addition to the estate in the period shortly before bankruptcy when a long-term creditor receives installment payments during the preference period. Thus, the long-term installment payment clearly results in the depletion of the bankruptcy estate for the benefit of a particular creditor, exactly the situation that preference law generally seeks to discourage.

Duncan, supra note 13, at 90 (footnotes omitted). 
flawed. If the transfer of payment is a preference, the payment, by definition, diminishes the estate that would otherwise be available for all creditors pursuant to section 547(b)(5). ${ }^{173}$ Furthermore, although goods purchased with short-term credit shortly before bankruptcy will probably still be in the estate, it is equally probable that a piece of machinery purchased on credit five years earlier will also still be in the estate. ${ }^{174}$

The argument that a payment to a short-term creditor does not diminish the debtor's estate involves an atteinpt to draw a line between short-term creditors and long-term creditors. The equality of distribution goal, however, distinguishes between creditors and noncreditors. Creditors are not treated unequally when a debtor transfers assets in an exchange with a noncreditor. For example, a merchant wlo sells goods for cash ${ }^{175}$ rather than for a claim to a future transfer does not share the risk that the debtor may have insufficient assets to satisfy future claims. In contrast, a creditor shoulders the risk of nonpayment equally with other creditors.

Some of the exceptions in section 547(c) recognize this difference by singling out transfers that resenble those made to a noncreditor who deals with the debtor only im exchange for immediate value. For example, section 547(c)(1) protects a transfer intended to be a contemporaneous exchange for new value given to the debtor and which is in fact a substantially conteinporaneous exchange. ${ }^{176}$ The section covers transfers made by check and a transfer of a security imterest in a substitution of

173. 11 U.S.C. $\S 547(b)(5)(1982)$ sets forth as an element of a preferential transfer the requirement that as a result of the transfer the transferee receive more than it would have received in a Chapter 7 proceeding if the transfer had not been made. Thus, "any transfer to a creditor within the 90-day period by way of payment on or security for an antecedent debt causes a depletion of the debtor's estate and, other elements being present, will constitute a voidable preference." 4 COLIIER ON BANKRUPTCY If 547.20, at 547-83 (15th ed. 1985). The diminution-in-estate notion comes from the 1898 Act. Cases decided under the 1898 Act held that "[t]o constitute a preferential transfer within the meaning of the Bankruptcy Act there must be a parting with the bankrupt's property for the benefit of the creditor and a consequent diminution of the bankrupt's estate" Continental \& Commercial Trust \& Sav. Bank v. Chicago Title \& Trust Co., 229 U.S. 435, 443 (1913). This requirement has been codified in section 547(b)(5), and perhaps in section 547(c)(1), the contemporaneous exchange exception. See Countryman, supra note 2, at 745, 766-67.

174. See DeSimone, supra note 13 , at 130.

175. A transfer cannot be on account of an antecedent debt if it is made for new value. "New value" is defined to include "money or money's worth in goods." 11 U.S.C. § 547(a)(2) (Supp. III 1985). Of course, the exchange must not be so unequal as to amount to a fraudulent conveyance. Id. $\S 548$ (1982 \& Supp. III 1985).

176. Section $547(c)(1)$ provides:

The trustee may not avoid under this section a transfer-

(1) to the extent that such transfer was-

(A) intended by the debtor and the creditor to or for whose benefit such transfer was

made to be a contemporaneous exchange for new value given to the debtor; and

$(B)$ in fact a substantially contemporaneous exchange....

11 U.S.C. $\$ 547(c)(1)(1982)$. 
collateral transaction. ${ }^{177}$ In both cases, the transfer may be a preference under the technical requirements of section $547(\mathrm{~b})$, but because it is, in essence, a contemporaneous exchange for new value, the other creditors' interests are not impaired and the policy of equality of distribution is not offended. The ordinary course of business exception, however, grants protection to a creditor who has agreed to deal with the debtor in return for a claim against the debtor's estate, rather than for immediate value. Thus, the exception is inherently inconsistent with the objective of equal distribution.

A second objective of the preference provision is to assist the debtor in working its way "out of a difficult financial situation through cooperation with all of his creditors" by discouraging creditors from engaging in the so-called "race of diligence."178 The House and Senate Reports accoinpanying the 1978 Code reiterate that section 547(c)(2) was designed to "leave undisturbed normal financial relations, because it does not detract from the general policy of the preference section [which is] to discourage unusual action by either the debtor or his creditors during the debtor's slide into bankruptcy."179

Some commentators have suggested that section $547(\mathrm{c})(2)$ should be extended to protect payments on long-term debt because (1) the longterm creditor is not likely to take part in a race to gain advantage over other creditors, and (2) regular payments on long-term debt constitute normal financial relations that should not be disturbed. ${ }^{180}$ This assertion, however, is strained for four reasons. First, the legislative history is misleading. After Congress removed the "reasonable cause to behieve" requirement in 1978, the inain goal of the preference provision was to preserve equality of distribution; the prevention of unusual pressure or action by the creditor becaine ouly an incidental objective. ${ }^{181}$ Second, and more importantly, there is no direct indication that Congress in-

177. 4 Collier on Bankruptcy I 547.37[2], at 547-124 to 547-125 (15th ed. 1985); Duncan, Delayed Perfection of Security Interests in Personal Property and the Substantially Contemporaneous Exchange Exception to Preference Attack, 62 NEB. L. REV. 201, 210-11 (1983).

178. H.R. REP. No. 595, 95th Cong., Ist Sess. 177-78, reprinted in 1978 U.S. CODE CONG. \& ADMIN. NEWS 5963, 6138. One commentator has argued that the preference provision does not deter the race of diligence, however, because "a preferred creditor can retain his preference if the ninety day period elapses before the bankruptcy petition is filed," and because if the petition is filed within 90 days of the payment, "the preferred creditor can escape all consequences of having been preferred by simply surrendering his preference." Countryman, supra note 2, at 748.

179. H.R. REP. NO. 595, 95th Cong., Ist Sess. 373, reprinted in 1978 U.S. CODE CONG. \& ADMIN. NEWS 5963, 6329; S. REP. No. 989, 95th Cong., 2d Sess. 88, reprinted in 1978 U.S. CODE CONG. \& ADMIN. NEWS 5787, 5874.

180. See supra note 14 and accompanying text.

181. H.R. REP. No. 595, 95th Cong., 1st Sess. 177-78, reprinted in 1978 U.S. CODE CoNG. \& ADMIN. NEWS 5963, 6138. 
tended to change this policy focus in the 1984 amendments. ${ }^{182}$ Congress rejected returning to the goal of preventing unusual action by declining to reinsert the "reasonable cause to beheve" requirement. ${ }^{183}$ The elimination of that requirement was one of the inost significant and debated changes to the preference provision inade by the 1978 Code. ${ }^{184}$ It seems unlikely that removal of the forty-five day requirement from section 547(c)(2) was intended to change the focus of the preference provision from equality of distribution to prevention of the race of diligence, especially in the absence of any discussion to that effect. 185

Third, commentators argue that section 547(c)(2), as amended, protects payments on long-term debt because these payments are within normal financial relations. ${ }^{186}$ These commentators rely on the legislative history accompanying the 1978 version of section 547(c)(2). ${ }^{187}$ This reliance on the "normal financial relations" concept is misplaced, however, because this phrase refers to payments on debt satisfying the ordinary course of business requirements and made within forty-five days of the date the debt was incurred. Since the statutory provision was specifically limited to short-term debt, it cannot be said that Congress intended "normal financial relations" to encompass payments on long-term debt.

Finally, declining to read section $547(c)(2)$ as extending to payments on long-term debt does not imply a complete rejection of the deterrence objective. Although deterring the race to dismember the debtor is not the major objective of the preference provision, deterrence is recognized in current sections $547(\mathrm{c})(2)(B)$ and (C), which require that payments be made (1) in the ordinary course of business of the debtor and the transferee and (2) according to ordinary business terms. ${ }^{188}$ A payment coinpelled by creditor pressure would not be afforded protection from avoidance.

If the ordinary course of busmess exception is inconsistent with the goal of equality, and if the protection of "normal financial relations" does not define the outer limits of the exception as amended in 1984, the problem of defining the outer limits of the exception remams. The resolution of this problem relates to the reasons behind preventing the race of diligence. Congress intended to deter the race of diligence in order to enable

182. See supra text accompanying note 165 .

183. See supra text accompanying notes 131-33, 147-48.

184. See supra text accompanying notes $80-93$.

185. See supra note 167.

186. See supra note 13.

187. See H.R. REP. No. 595, 95th Cong., 1st Sess. 373, reprinted in 1978 U.S. CODE CoNG. \& ADMIN. NEWS 5963, 6329; S. REP. No. 989, 95th Cong., 2d Sess. 88, reprinted in 1978 U.S. CODE CONG. \& ADMIN. NEWS 5787, 5874.

188. 11 U.S.C. $\$ 547(c)(2)(B)$, (C) (Supp. III 1985). See supra text accompanying notes 34-43. 
the debtor "to work his way out of a difficult financial situation through cooperation with all of his creditors."189 This statement indicates that Congress intended to encourage ${ }^{190}$ ordinary transactions that may keep the debtor in business. ${ }^{191}$ This goal suggests a way to distinguish between debt incurred in the ordinary course of the debtor's business and debt that is not so incurred.

Section 547(c)(2) encourages creditors to extend short-term credit to finance a troubled debtor's current operations. In most instances, a creditor's decision to lend money to a debtor depends on whether the creditor believes the debtor will be able to repay the loan when due and whether the creditor believes the debtor will not enter a bankruptcy proceeding for ninety days thereafter. A short-term creditor evaluating the risk of nonpayment might be fairly confident that the debtor will be able to repay the debt when due froin the proceeds of the current operations financed by the debt. For instance, a creditor extending credit to finance the debtor's purchase of raw materials may view the proceeds arising from later sales of the finished goods as the source of funds to repay the loan. If the short-term creditor believes that the risk of nonpayment is minimal, it must still evaluate the likelihood that the debtor will enter a bankruptcy proceeding within ninety days after the payment. If the ordinary course of business exception is not available, then a debtor (especially one experiencing temporary financial difficulty) might be unable to borrow to finance its current operations. In contrast, the extension of section $547(c)(2)$ to cover payments on long-term debt does not signifcantly affect the long-term creditor's initial decision to make a loan. For example, suppose the creditor contemplates a five-year loan to be repaid in monthly imstallments. Interpreting section 547 (c)(2) to extend to payments on long-term debt only affords protection for ninety days of payments received at the end of a sixty month payback period. Protecting these payments from avoidance will not significantly alter the creditor's risk of the debtor's insolvency, and thus offers little inducement to a creditor to extend long-term debt.

189. H.R. REP. No. 595, 95th Cong., 1st Sess. 177, reprinted in 1978 U.S. CODE CONG. \& ADMIN. NEwS 5963, 6138.

190. Professor Herbert argues, however, that the legislative history suggests that section $547(c)(2)$ was not designed to encourage anything, but was designed merely to avoid penalizing the unknowing recipient of a preference. Herbert, supra note 112, at 670 \& n.14.

191. See Morrow v. United States (In re Morris), 53 Bankr. 190, 192 (Bankr. D. Or. 1985) ("This court believes that the purpose of $\S 547(c)(2)$ was to encourage creditors to continue shortterm credit dealings with troubled debtors in order to forestall bankruptcy rather than encourage it."). "[C]reditors may continue doing business with the debtor because they will not be penalized if the debtor's attempt to function outside of bankruptcy fails." Countryman, supra note 2, at 775. 
In addition, preserving the trustee's ability to avoid payments to a long-term creditor may further the goal of preventing the debtor's bankruptcy. ${ }^{192}$ Suppose a debtor is unable to meet all of its financial obligations, including a regularly scheduled payment to a long-term creditor, and asks the long-term creditor for an extension so that it may meet its obligations to suppliers with whom it must deal to continue its operations. If section 547(c)(2) protects any regular payment received by the long-term creditor from avoidance, the creditor may insist on its regular payment knowing that it will not be avoidable if the debtor enters bankruptcy within the following ninety days. If section 547(c)(2) does not protect regular payments on long-term debt from avoidance, the creditor has an incentive to work with the debtor so that the debtor may overcome its temporary financial difficulties, stay out of bankruptcy, and eventually meet all of its obligations in full.

Thus, the goal of encouraging creditors to deal with the debtor suggests a way to distinguish between debt incurred in the ordinary course of the debtor's business and debt that is not so incurred.193 This distinction, as suggested above, may depend on whether the debt is short-term or long-term because the extension of short-term credit is necessary for the continuing operations of the debtor. Although determining where to draw the line separating short-term and long-term debt may seem impractical, ${ }^{194}$ similar lines are drawn in other areas. ${ }^{195}$ For instance, accountants draw a similar distinction when classifying habilities to be reported on a corporation's balance sheet as either current or long-term.

Under generally accepted accounting primciples, the term "Iongterm liabilities" typically is used to refer to debt used to finance the acquisition of fixed assets. Debtors expect to repay long-term debt from increased cash flow and profits generated over the next few years from

192. See supra notes $\mathbf{1 8 9 - 9 1}$ and accompanying text.

193. Professor Countryman suggests that if the justification for section $547(\mathrm{c})(2)$ is to encourage creditors to enter into ordinary transactions that inay keep the debtor from failing, payments on all debt should be protected because all debt-trade debt, short-term bank notes, and long-term installment obligations-may be equally important in keeping the debtor in business. Countryman, supra note 2 , at 775-76.

194. As one commentator asks:

[H] fuzzy. It will no doubt take years for the courts to consistently define short-term and when they do the decision will be little more than arbitrary judicial line drawing.

DeSimone, supra note 13, at 129.

195. The distinction between capital expenditures and currently deductible operating expenses for income tax purposes poses a similar line-drawing problem. See generally Note, Distinguishing Between Capital Expenditures and Ordinary Business Expenses: A Proposal for a Universal Standard, 19 U. Mich. J.L. REF. 711 (1986); Note, Income Tax-Costs of Expanding an Existing Business: Current Deductions Versus Capital Expenditures-North Carolina Bank Corp. v. Uinted States, 18 WAKE FOREST L. REv. 1127 (1982). 
the use of the fixed assets, rather than from current operations. ${ }^{196}$ The term "current liabilities" is used to "designate obligations whose hquidation is reasonably expected to require the use of existing resources properly classifiable as current assets, or the creation of other current liabilities."197 The term "current assets" designates those assets that are expected to be realized in cash, sold, or consumed during the "operating cycle"-the usual time between the acquisition of materials or services entering the production process and the final cash realization froin the sale of the finished products or services. ${ }^{198}$ Current liabilities include "obligations for items which have entered into the operating cycle, such as payables incurred in the acquisition of materials and supplies to be used in the production of goods or in providing services to be offered for sale . . . and debts which arise from operations directly related to the operating cycle." 199

196. Long-term debt is "normally used to finance fixed assets or permanent additious to working capital. Repayment usually must come from profits rather than from liquidation of the assets financed, as in the case of seasonal short-term loans." J. PRINGLE \& R. HARRIS, supra note 105, at 462. Thus, long-term lenders are "more concerned with [the debtor's] income statement, looking for their security to the [debtor's] earning power over sustained periods of time." Id. at 643.

Nor is it likely that a debtor would be able to use short-term debt to finance long-term needs. According to generally accepted accounting principles, short-term obligations must be excluded from classification as current liabilities if the debtor intends to refinance the obligation on a longterm basis and is able to do so. STATEMENT OF FinaNCIAL AccounTiNg STANDARDs 6 (Fimancial Accounting Standards Board 1975). Moreover,

[b]anks often require borzowers to "clean up" their short-term loans for at least one month each year; this prevents firms from using bank credit as a source of permanent financing. As the borrowing firm's inventories and receivables are liquidated during the slack season, the firm should be able to repay the loan. Then, if the firm's repayment performance has been satisfactory, the bank will again provide a line of credit to meet the firm's seasonal financing needs during the next year. If the firm is chronically unable to become free of bank debt for a part of each year, this suggests a need for nore long-term capital.

F. Weston \& E. Brigham, supra note 105, at 257; accord J. Pringle \& R. HarRis, supra note 105, at 660. Contra Viscione, How Long Should You Borrow Short Term?, HaRv. Bus. REV., March/April 1986, at 20 ("Smaller companies often use short-term loans to finance permanent investments in working capital."). Nor do "current liabilities" include "long-term obligations incurred to provide increased amounts of working capital for long periods." RESTATEMENT AND REVISION of Accounting Research Bulletins, Accounting Research Bulletin No. 43, ch. 3, § A8 (Am. Inst. of Certified Pub. Accountants 1953) [hereinafter ARB No. 43].

197. ARB No. 43, supra note 196, ch. $3, \S$ A7.

198. Id. ch. $3, \S$ A5. Most businesses have more than one operating cycle per year. J. BuRTON, R. PAIMER \& R. KAY, HANDBOOK OF ACCOUNTING AND AUDITING 3-14 (1981).

199. ARB No. 43 , supra note 196, ch. $3, \S$ A7. Although the generally accepted accounting definition of current liabilities is helpful in suggesting a distinction between what I have called shortterm and long-term debt, the accounting definition should not be directly applied. "Current liabilities" include the current portion of long-term debt. Obviously, this definition of current liabilities is helpful only if we consider short-term debt to be comparable to liabilities that are initially classified as current on the debtor's balance shcet (and not the currently due portions of liabilities which were initially classified as long-term on the debtor's balance sheet). In addition, accountants classify as current liabilities all those liabilities expected to be repaid during the longer of one year or the debtor's operating cycle. Because section $547(\mathrm{c})(2)$ is an exception to the preference provision and to 
For instance, assume the debtor manufactures baseball bats. Its operating cycle is determined by the length of time it takes to purchase the wood used to make the bats, manufacture the bats, sell the bats to sporting goods stores, and collect the resulting accounts receivable. A debt incurred to purchase the wood for the bats would be classified as a current liability if the debt's term was shorter than the debtor's operating cycle, indicating that the debt was indeed incurred to finance the current operations of the debtor. In contrast, a financially troubled debtor may teinporarily postpone incurring long-term debt to finance fixed assets. If the debtor's financial condition does not improve sufficiently so as to inake a creditor willing to extend long-term debt, bankruptcy policy should not serve to encourage loans to a debtor whose liabilities continually exceed its assets. If the debtor's financial difficulties are permanent, rather than teinporary, its assets should be liquidated in a bankruptcy proceeding and directed to more profitable uses.

Even if it is possible to distinguish between short-term and longterm debt, soine miglit argue that section 547(c)(2) should be read even more narrowly to include only trade credit.200 There is seemingly no justification, however, for distinguishing among the three sources of short-term debt-trade credit, slrort-term loans from banks or other financial institutions, and commercial paper-in determining whether a debt is incurred in the ordinary course of the debtor's business. Different treatment of sliort-term debt based on the source of funds miglit discourage a debtor from obtaining the least expensive financing. For instance, sliort-term bank debt often carries a lower interest rate than trade credit extended by a supplier of goods, and the interest rate on commercial paper issues is typically one to one and one-half percentage points lower than the prime rate offered by many banks. ${ }^{201}$ There is no defensible

the general policy of equality of distribution, it sliould be construed narrowly. Thus, to the extent accounting principles inform a distinction between slort-term and long-term debt, short-term debt should include only those liabilities that are used to finance current operations during the debtor's operating cycle, and sliould not extend to include liabilities that will be repaid within one year if the debtor's operating cycle is less than one year.

200. See Aguillard v. Bank of Lafayette (In re Bourgeois), 58 Bankr. 657, 660 (Bankr. W.D. La. 1986) (suggesting that section 547(c)(2) "was intended to apply to trade credit transactions" rather than long-term debt).

201. Assune a buyer purcliases goods on account and the seller is willing to give a two percent price discount if payment is received within 10 days after the sale or will alternatively aecept the full purcliase price if paynnent is received within $\mathbf{3 0}$ days after the sale. This is a normal trade credit term called " $2 / 10$, net 30 ." If the buyer forgoes the discount and pays the full purcliase price on the thirtieth day after purchase, the cost of not taking the discount is $37 \%$ on an annualized basis. $J$. PRINGLE \& R. HARRIS, supra note 105, at 656-58; J. WESTON \& E. BRIGHAM, supra note 105, at 261.63. Bank debt, of course, often carries additional costs beyond the stated interest rate that must be considered in computing the debtor's actual costs of funds. For instance, the "borrower should expect to bear certain costs which will include the fees of its own counsel, and printing and other 
reason to allow a payment to a trade creditor to stand, but to avoid a payment to a bank creditor if the debtor chose to finance its inventory purchases with a less expensive short-term bank loan rather than with more expensive trade credit offered by a supplier.

The legislative history of the ordinary course of business exception indicates that Congress intended the exception to comprehend payments to trade creditors. ${ }^{202}$ There are also indications that Congress assumed that commercial paper could be issued in the ordinary course of a debtor's business. Congress conducted hearings on problems experienced by commercial paper issuers under the 1978 Code. ${ }^{203}$ The focus of the discussion was not whether commercial paper could be issued in the ordinary course of a debtor's business, but whether the maturities of commercial paper issues had been artificially limited by section $547(\mathrm{c})(2)$ to less than forty-five days. ${ }^{204}$ Moreover, when the forty-five day provision was removed in 1984, Senators Dole and DeConcini asserted that "companies that have a need for short-term funds, and investors who wish to purchase short-term obligations, would both be acting in their respective 'ordinary course of business or financial affairs' if they were to deal directiy or indirectly with each other in the commercial paper market."20s Presumably, short-term debt from other sources, such as banks or other financial institutions, may also be incurred in the ordinary course of the debtor's business.

A final question is how to distinguish between a debt that may be incurred in the ordinary course of financial affairs of a consumer debtor and a debt that may not be so incurred. The line between short-term and long-term debt may be harder to draw in the case of a consumer debtor than in the case of a business debtor. Current liabilities of an individual include all liabilities with a maturity of less than one year. This period is arbitrarily cliosen for administrative convenience. Althougli it is difficult to conceptualize an operating cycle of a consumer debtor, it is possible to suggest that since a wage earning consumer realizes the earnings from his

out-of-pocket expenses of the lender related to the transaction." COMMITTEE ON DEVELOPMENTS IN BUSINESS FinANCING, supra note 71 , at 50.

Similarly, the issuance of commercial paper may be a less expensive source of funds than shortterm bank credit for those companies that have access to the market. Interest rates on commercial paper generally run about $1.5 \%$ below the prime rate. J. PRINGLE \& R. HARRIS, supra note 105 , at $667-68$; J. Weston \& E. BRIGHAM, supra note 105 , at 272 . See supra note 116.

202. See supra text accompanying notes $98-100$.

203. See supra text accompanying notes 115-17.

204. See supra note 118 and accompanying text.

205. 130 CONG. REC. S8897 (daily ed. June 29, 1984, pt. In) (statement of Sen. DeConcini) (emphasis added). See supra note 155. 
employment in monthly or biweekly pay intervals, that period approximates the consumer's "operating cycle."

Perhaps in recognition of the trouble that might be encountered in determining the kinds of clebts incurred in the "ordinary course" of a consumer debtor's "financial affairs," Congress enacted section 547(c)(7) as part of the 1984 amendments. The exception protects from preferential avoidance each transfer by a consumer debtor if "the aggregate value of all property that constitutes or is affected by such transfer is less than $\$ 600 . " 206$ The addition of section $547(c)(7)$ effectively eliminates, in the case of most consumer payments, the necessity of determining whether the debt was incurred and payment made in the ordinary course of the financial affairs of the consumer.

The addition of section 547(c)(7) may also represent Congress's attempt to respond to many of the concerns voiced by creditors of consumer debtors without interfering with the established poticies of the preference provision for debts other than consumer debts. For instance, creditors complained that avoidance of small payments made by consumers on installment debts did not, in practice, further the equality of distribution goal since the amounts recovered were usually not great enough to offset the administrative expenses associated with the recovery effort. The addition of this special exception suggests Congress did not mean to expand the scope of the ordinary course of busmess exception contrary to the bankruptcy goal of equality.

\section{CONCLUSTION}

The ordinary course of business exception, as amended in 1984, should not be read so broadly as to protect payments on long-term debt froin preferential avoidance. Although many have concluded that this is the inevitable result of the removal of the requirement that the payment be made within forty-five days of the incurrence of the debt, that conclusion is not justified. Such an expansive interpretation would seriously impair the effectiveness of preference law and the goal of equality of distribution of an insolvent debtor's assets to its creditors. The legislative history of the ordinary course of business exception and the policies underlying it suggest an appropriate limiting principle: the exception only protects payments on debts incurred in the ordinary course of the debtor's business, and only short-term debt incurred to finance the debtor's current operations-that is, debt to be repaid in the nonnal operating cycle of the debtor-may be deemed incurred in the ordinary course.

206. 11 U.S.C. $\$ 547(c)(7)$ (Supp. III 1985). 